\title{
RESEARCH OPTIONS FOR THE DEVELOPMENT OF SENSORS TO MEASURE THE THERMAL STATE OF SOLID STEEL BODIES
}

\author{
By \\ T. A. Gaspar \\ H. W. Lownie, Jr.
}

February 1983

Work Performed Under Contract No. AC06-76RL01830

Battelle Columbus Laboratories

Columbus, Ohio

\section{U. S. DEPARTMENT OF ENERGY}




\title{
DISCLAIMER
}

\begin{abstract}
"This report was prepared as an account of work sponsored by an agercy of the linited States (jovernmint. Neither the United States Govermment nor any agency thereof, nor any of thei: empioyses, makes any warranty. express or implied, or assumes any legal liability or responsibility for the accuracy, cumpleteress, or usefulness of any information, apparatus. product, ar rrocess disclosed, or represents that its use would not infringe privately owned rights. Reference herein to any peafic eorrmercias product, process, or service by trade nane, rademark. ianufacture, or otherwise, does not reessarily constitute or imply its endorsement, roommendation, or favoring by the United states Govemment or any agency therear. The vews and opinions of author expressed herein do rot necessarily state or tefloct those of the United States Government or any agency ihereof:
\end{abstract}

This report has been reproduced directly from the best available copy.

Available from the National Technical Information Service, U. S. Department of Commerce, Springfield, Virginia 22161 .

\section{Price: Printed Copy A03}

Microfiche A01

Codes are used for pricing all publications. The code is determined by the number of pages in the publication. Information pertaining to the pricing codes can be found in the current issues of the following publications, which are generally available in most libraries: Energy Research Abstracts, (ERA); Government Reports Announcements and Index (GRA and I); Scientific and Technical Abstract Reports (STAR); and publication, NTTS-PR-360 available from (NTIS) at the above address. 
PNL-4592

(DE83007253)

Distribution Category UC.95f

RESEARCH OPTIONS FOR THE

DEVELOPMENT OF SENSORS TO MEASURE

THE THERMAL STATE OF SOLID STEEL BODIES

to

PACIFIC NORTHWEST LABORATORY

Memorandum Purchase Order B-D-2074-A-5

In Support of

THE DEPARTMENT OF ENERGY

OFFICE OF INDUSTRIAL PROGRAMS

PNL Contract Number 80580

February 1983

by

T.A. Gaspar

H.W. Lownie, Jr

BATTELLE

Columbus Laboratories

505 King Avenue

Columbus, Ohio 4320] 


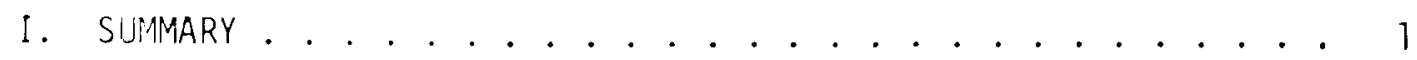

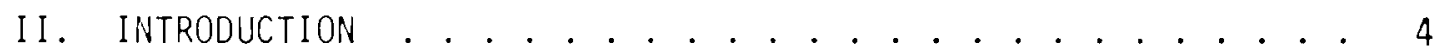

III. RESEARCH PROCEDURE . . . . . . . . . . . . . 6

IV. CUJRENT PRACTICES ................. . . . . 6

Surface Temperature .......... . . 7

Modeling .............. . . 9

Experimental Verification of Models . . . . . . . 9

V. INTERNAL-TEMPERATURE MEASUREMENT .......... 12

Nondestructive Tests . . . . . . . . . 13

Identification of Possible Nondestructive Test Methods ............. . . 13

VI. UTILITY OF THERILAL-PROFILE SENSOR IN EXISTING FACILITIES . . 26

Continuous Casting . . . . . . . . 27

Ingot Production and Breakdown . . . . . . . 33

Reheat Furnaces . . . . . . . . . . . 35

VII. PROSPECTS IN NEW FACILITIES . . . . . . . . . . 38

Direct Rolling . . . . . . . . . . . . . 39

Liquid-Center Charging and Rolling ..... . . 39

Hot Charging . . . . . . . . . . . 42

Controlled Solidification......... 43

VIII. RESEARCH RECOMMENDATIONS .............. . 44

Real-Time Measurement of the Location

of the Solid/Liquid Interface........ 49

Real-Time Measurement of the Average Internal Temperature of Hot Steel Bodies . . . . 51

Real-Time Measurement of Internal-

Temperature Gradients of Hot Steel Bodies... . 53

REFERENCES ........................ 55

APPENDIX A: SURVEY GUIDE AND FLOWCHART ............ A-1-A-2

APPENDIX B: LIST OF INDIVIDUALS CONTACTED DURING THE STUDY .B-1--B-5 
FIGURE IV-1. DUAL PYROMETER SYSTEM USING FURNACE WALL AS REFERENCE ................ . . 8

FIGURE IV-2. DUAL PYROMETER SYSTEM USING COOLED PLATE AS REFERENCE ................ 8

FIGURE IV-3. SCHEMATIC DIAGRAM OF HORIZONTAL PROBING TECHNIQUE .................... 11

FIGURE IV-4. PHOTOGRAPH OF FEDESCO'S EMBEDDED THERMOCOUPLE SYSTEM MOUNTED ON A STEEL SLAB. . . . . . 11

FIGURE $V-1$. SCHEMATIC OF "MUSHY ZONE" DURING STEEL SOLIDIFICATION . . . . . . . . . . . . . . 12

FIGURE V-2. LONGITUDINAL ULTRASONIC WAVE VELOCITY AS A FUNCTION OF TEMPERATURE FOR DIFFERENT STEELS . . . 15

FIGURE $V-3$. ULTRASONIC VELOCITY AS A FUNCTION OF TEMPERATURE FOR DIFFERENT CAST IRONS . . . . . 16

FIGURE V-4. VELOCITY OF LONGITUDINAL ULTRASONIC WAVES IN NON-FERROUS PURE METALS AS A FUNCTION OF TEMPERATURE . . . . . . . . . . . . . 17

FIGURE V-5. ATTENUATION OF $0.5 \mathrm{MHz}$ ULTRASONIC SIGINAL WITH TEMPERATURE FOR $0.47 \%$ CARBON STEEL $\ldots . . .17$

FIGURE V-6. SCHEMATIC OF NIPPON STEEL SYSTEM TO MEASURE SOLIDIFICATION SHELL THICKNESS IN CONTINUOUSLY CAST STEEL STRANDS . . . . . . . . . . . 18

FIGURE $V-7$. SOLIDIFICATION SHELL THICKNESS AND OTHER EXPERIMENTAL PARAMETERS MEASURED WITH NIPPON STEEL SYSTEM . . . . . . . . . . . 18

FIGURE V-8. SCHEMATIC OF SOVIET FAZA-2 SYSTEM FOR MEASURING SOLIDIFICATION SHELL THICKNESS . . . . 21

FIGURE V-9. RESISTIVITY AND FIRST DERIVITIVE di / dT OF AN IRON STANDARD WITH TEMPERATURE ...... 23

FIGURE V.10. SCHEMATIC OF COIL PLACEMENT IN MOLD OF CONTINUOUS CASTING MACHINE AT NORTH STAR STEEL . . 25 
LIST OF FIGURES

(Continued)

Page

FIGURE VI-1. SCHEMATIC OF SOLIDIFICATION OF STEEL

AND ALUIIINUM DURING CONTINUOUS CASTING . . . . . 23

FIGURE VII-1. SCHEMATIC OF FLOW OF HOT-CHARGED

DIRECT-ROLLING SYSTEMS . . . . . . . . . . . 40

FIGURE VIII-1. RESEARCH MATRIX COMBINING MEASUREMENT

GOALS WITH STEELMAKING APPLICATIONS . . . . . . 46

FIGURE VIII-2. RESEARCH MATRIX COMBINING PHYSICAL

PRINCIPLES WITH STEELMAKING APPLICATIONS . . . . 47

FIGURE VIII-3. RESEARCH MATRIX COMBINING PHYSICAL

PRINCIPLES WITH MEASUREMENT GOALS . . . . . . . . 48

FIGURE VIII-4. TREE DIAGRAM OF EXISTING RESEARCH ALTERNATIVES

TO MEASURE THE LOCATION OF THE SOLID/LIQUID

INTERFACE OF STEEL DURING SOLIDIFICATION . . . . . 50

FIGURE VIII-5. TREE DIAGRAM OF RESEARCH ALTERNATIVES TO MEASURE

AVERAGE INTERNAL TEMPERATURE OF HOT STEEL BODIES . 52

FIGURE VIII-6. TREE DIAGRAM OF RESEARCH ALTERNATIVES TO

MEASURE INTERNAL TEMPERATURE OF HOT STEEL BOUIES . 54

\section{LIST OF TABLES}

TABLE VI-1. ANNUAL POTENTIAL ENERGY SAVINGS FROM MEASUREMENT OF THERMAL STATE IN CONTINUOUS CASTERS . . . . . . . 31

TABLE VI-2. CONTINUOUSLY CAST ROUNDS AND BILLETS . . . . . . . 32

TABLE VI-3. CONTINUOUSLY CAST BLOOHS AND SLABS . . . . . . . . 32

TABLE VI-4. POTENTIAL ENERGY SAVING FROM MIASUREMENT OF

THERMAL STATE IN SOAKING PITS AND BREAKDOWN MILL . 34

TABLE VI-5. POTENTIAL ENERGY SAVINGS FROM MEASURED THERMAL

STATE IN REHEAT FURNACES AND ROLLING OPERATIONS • 37 
. 


\section{SIJMMARY}

The purpose of the study reported here is to assist Battelle's Pacific Northwest Laboratory (PNL) in planning a research and development program to develop temperature sensors for metal and ceramic industries. This study focuses on sensors to neasure internal temperature distributions within bodies of hot steel. A series of literature surveys, interviews, field visits, and meetings with steel-industry organizations was conducted in seeking answers to six questions posed by Pill. These questions, with our responses, are summarized below.

- Does technology exist to allow the development of devices for "measuring" internal temperatures?

Yes, in the context of providing a basis for nondestructively measuring temperature gradients through bodies of hot steel, including bodies with molten centers. The technologies that have been identified for use in internal-temperature measurement stem from four different physical principles: acolistic velocity, thermal expansion, neutron thermalization, and e?ectrical conductivity. Specific techniques involve: ultrasonic transmission, eddy currents, gamma attenuation, dilatometry, and energetic neutrons, anong others.

A major problem at this stage of the research is to select from among these physical principles the one or two that seem to offer the most promise for success within a reasonable time, and, fromit, to develop a technology for internal temperature-gradient measurements.

- Will the developinent of these devices ailow industry to save significant quantities of energy?

Yes. The identifiable potential energy savings for three major applications in the steel industry (continuous casting, ingot heating and breakdown, and reheat furnaces) is about $90 \times 10^{12}$ Btu/year $(0.09$ Quad/year). To this would be added energy savings from other applications in the steel, nonferrous metal, and ceramic industries.

The main driving force promoting implementation by the steel industry might well be perceived benefits resulting from higher quality and higher productivity, rather than energy conservation per se. 
- Is anyone developing these devices?

Yes. The development of internal temperature-gradient mapping systems has stimulated entrepreneurial nondestructive testing research. But the extent of real progress that has been made to date is cloudy. A number of investigations seem to have been dropped in midstream. There remains a possibility that someone somewhere may momentarily unveil a practical system adaptable to all steelriaking applications. The likelihood of this happening is judged to be low. However, our open survey carries the risk that we have not identified some proprietary development that might even be the sought-for breakthrough.

- Does industry plan to develop or support the development of this technology?

Yes. The American Iron and Stecl Institute (AISI) is co-sponsoring a workshop on Process Control Sensors for the Steel Industry, July, 27-28, 1982. It will feature measurement of thermal state as one of four main research objectives. Although key individuals in AISI and its member organizations see high potential for a successful system, they are construined by budgets. The potential dollar savings that could result from a successful device is large. But steel companies are faced with an imposing array of alternative uses for funds, some of which are associated with survival rather than improvement. As a resuit, the extent to which the steel industry will support internal development of new sensors is unclear.

The steel industry is likely to encourage and support specific research programs aimed at industrial applications that offer a high probability for success within the next few years.

- Can a "successful" research program be devised?

Yes, subject to the caveat that "success" needs to be defined. If it means learning more about how to make the desired measurements on a practical and cost-effective basis, the "success" of a program of sufficient scope, time, and funding is likely. If "success" means the attainment of the objective of coming up with a practical and cost-effective device, any program that we can currently visualize must be considered high-risk and long-term. 
- Who is capable of conducting an R\&D program?

A number of domestic and foreign investigators and organizations have attacked various aspects of the problem. They have provided the background for conducting this Battelle-Columbus study. They have made contributions, some positive, some negative, but each of which contributed to progress. The leaders in the development of sensors include: steel companies, nondestructive-evaluation companies, national and private laboratories, universities, and foreign governments. Additional organizations are capable of conducting research if external support and guidance are provided.

\section{Recommendations}

Recommendations include the following:

- Research aimed at measuring the location of the solid/ liquid should not be pursued by PNL.

- PNL should not pursue measurement of average internal temperature as an overall objective.

- PNL should pursue measurement of internal temperature distribution in hot steel bodies as its principal research objective.

- If only one technology is to be selected to initiate a sensor development program, it is recommended that research be focused on acoustic mapping techniques, which appear to represent the most generic solution to measurement of internal temperature distributions.

- The most appropriate level of activity for the next phase of this study combines focused technical analysis with preliminary laboratory investigations. 


\section{INTRODUCTION}

This study was authorized in December 1981 and initiated in Janliary 1982 on the basis of a subcontract from the Pacific Northwest Laboratory (PNL) to Battelle's Columbus Laboratories (BCL).

The objective of the PNL project is to support the Department of Energy's research and develooment program to improve the energy efficiency in the metals and ceramics industries. As part of the project, PNL will select and manage a research team qualified to identify sensing methods that could be used to determine the thermal state of hot solids; for example, metal ingots, slabs, blooms, and plates, as well as ceramic products. A second phase of the PNL project, assuming a successful first phase, would be the development and testing of practical sensors that could be used on a production basis; that is, measuring temperature profiles during industrial operations such as continuous casting; ingot production; soaking of ingots; reheating of slabs, blooms, and billets; hot rolling; and heat treatment.

The $B C L$. subcontract represented by this report is in support of the PNL project. More specifically, the BCL subcontract is oriented toward sensors that measure the average temperature and/or temperature gradients within a body of hot steel.

The subcontract provides for BCL to aid PNL in planning the PNL program on high-temperature sensing by collecting and evaluating opinions on a number of questions. These questions are:

- Does technology exist to allow the development of devices for "measuring" internal temperatures?

- Will the development of these devices allow industry to save significant quantities of energy?

- Is anyone developing these devices?

- Does industry plan to develop or support the development of this technology?

- Car a "successfu1" research progral" be devised?

- Who is capable of conducting an Res program? 
Early in the $B C L$ study, attention was given to the fact that Task Group 5-4 of the American Iron and Steel Institute (AISI) has independently begun study of the potential and problems of high-temperature sensors. A decision had to be made about the degree of interaction between the two studies (BCL and AISI). This was facilitated by a meeting in February 1982 involving individuals representing Battelle, PNL, Task Group 5-4, AISI staff, and The DOE Office of Industrial Programs (OIP). A high degree of rapport was established, and was maintained throughout the remainder of the BCL study, both in meetings and in individual discussions. The decision was to exchange information, data, and opinions freely on an informal basis, but to maintain the independence of the BCL and AISI studies, recognizing that the two studies might result in different reconmendations and actions.

One of the inherent differences between the BCL and AISI studies is in the time frame. The $B C L$ study was scheduled to result in a draft report, including recommendations to $\mathrm{PNL}$, following the fifth month of work (May 1982). The AISI study is following a more extended time schedule, so that its recommendations may not be forthcoming for some additional months. One of the similarities that has evolved in both the BCL and AISI studies is agreement on the desirability of developing a technique to measure tenperature gradients through bodies of hot steel. Although this appears to be the most desirable and most useful end result, investigators involved in both studies recognize that because gradient-mapping presents formidibie technical problems, alternatives involving lesser degrees of difficulty may be developed as stepping stones to the ultimate objective of gradient-mapping.

The sensors under consideration in this BCL study are devices and systems for the real-time measurement of temperature. As such, they are different from "models" that infer or predict temperatures based nostly on mathematical analysis. Modeling of casting and hot-working processes is being practiced, largely because of the lack of suitable and practical technology to measure temperature gradients. In the long run, modeling and direct measurement will probably coexist, with each being used in particular situations. Indeed, one of the useful applications of direct measurement would be to confirm and to calibrate models. 


\section{RESEARCH PROCEDURE}

The results of this study were obtained from the following sources:

- Literature surveys of Engineering Information, Metals Abstracts, Alloys Index, and Information Service in Mechanical Engineering were conducted for temperature measurement of hot solid steel. In addition, a search of Soviet patent and technical literature was conducted, as well as a survey of Science Abstracts for possible experimental techniques.

- A series of telephone interviews was conducted with individuals from industry, academia, and government to survey the need for measurement of the thermal state of solids and the extent to which such measurements are practically obtainable. The telephone-conversation flowchart presented in Appendix A illustrates the format followed during these conversations.

- Field trips were made to major steel companies, including mill visits and group discussions.

- Meetings were held with the American Iron and Steel Institute (AISI) Task Group 5-4 on Sensors to Measure Temperature Profile of Hot Solid Steel Bodies, and with a consultant to the Canadian Steel Industry Research Association (CSIRA) who is evaluating quality-control sensors for the Canadian steel industry.

- Discussions and interviews were held with Battelle scientists involved in physical and optical systems, nondestructive evaluation, and laser processing of materials.

A listing of individuals who were contacted during the course of this study is given in Appendix $B$.

\section{CURRENT PRACTICES}

Currently, therinocouples and pyrometers are the most widely used devices to measure temperatures in the steel industry. These devices measure an object's surface temperature by radiation or contact. These techniques will be discussed, along with attempts to calculate thermal state by numerical modeling. Finally, experimental verifications of numerical models are surveyed. 


\section{Surface-Temperature Measurements}

Thermocouples and pyrometers are used extensively to measure surface temperatures of solid steel. Thermocouples generally consist of joined wires of two dissimilar metals. The junction is used as a temperature probe. An electromotive force created at the junction is proportional to the difference bewteen the temperature at the junction and a reference teriperature.

Pyrometers measure the changes in radient energy of a heated object. Two types of detectors are used: photoelectric detectors, which produce electrons as the radiant energy excites their surface, and photoresistive detectors, which change their electrical resistivity when irradiated. Commercial pyrometers typically measure total radiation, a single waveband of radiation, or two wavelengths (two-color ratio pyrometers).

In practice, surface-temperature measurements of steel made with pyrometers may deviate from the true value by $100 \mathrm{C}$ or more. Factors contributing to measuring errors include, but are not limited to: changes in enissivity due to scale, surface defects, water and steam; reflected radiation from furnace walls, heat tubes, and flames; and improper maintenance.

Systems are available to compensate for some measurement errors. One device combines a de-scaler with an optical pyrometer to measure the surface temperature of continuously cast strands. ${ }^{*}$ A second technique incorporates dual pyrometers to compensate for errors caused by reflected radiation. (2) One of the pyrometers measures the steel surface temperature, while the other measures either the furnace-wall temperature (Figure IV-1) or the temperature of a referenced plate (Figure IV-2) or closed tube. Both of these systems are used industrially.

Infrared thermography is another technique that is used in steel mills for surface-temperature measurement. (3) Infrared thermography uses a thermal-imaging camera to produce TV-type images in which different surface temperatures are represented by different colors. Sumitomo Metal Industries, Ltd. has reported the use of the system on a continuous caster to observe uneven cooling at the corner of slabs during continuous casting

* List of references on pp 55-58. 


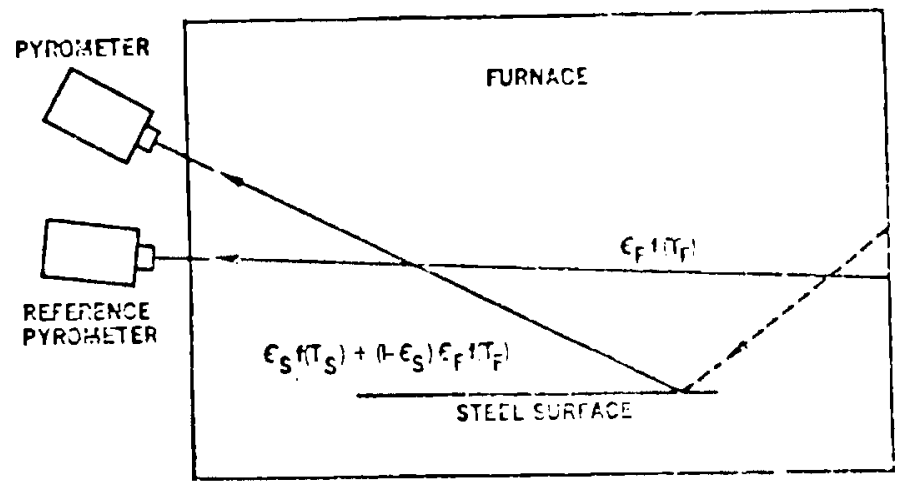

FIGURE IV-1. DUAL PYROMETER SYSTEM USING FURNACE WALL AS REFERENCE (2)

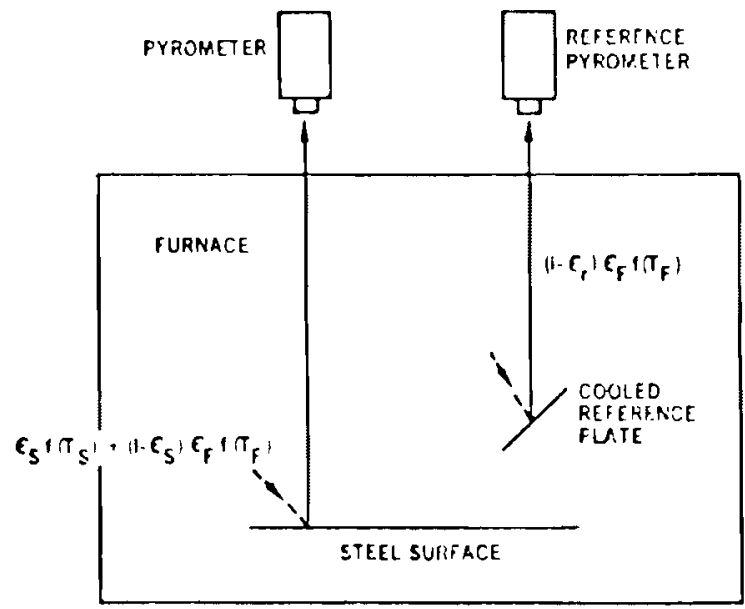

FIGURE IV-2. DUAL PYROMETER SYSTEM USING COOLED PLATE AS REFERENCE (2) 
at the Kashima Steel Works. (4) The camera is mounted 8.5 meters (about 28 feet) from the meniscus and monitors temperatures in the range of $750-800 \mathrm{C}$ $(1380-1470 \mathrm{~F})$.

The infrared scanning radiometer has been combined with numerical models for predicting internal cavities in steel from surface isotherms. Although these tests were performed at comparatively low temperatures (about $35 \mathrm{C}$ ), it has been suggested that unsteady thermotopography and numerical modeling would be combined to predict internal temperature gradients at higher temperatures. Measurements up to $2000 \mathrm{C}$ are obtainable by infrared thermography.

\section{Modeling}

Numerical solutions for calculating internal temperature profiles in hot solid or solidifying steel are beginning to be used for real-time monitoring of continuous casting, ingot solidification, soaking pits, reheat furnaces, annealing furnaces, and rolling operations. Variables that are used as inputs to computer models include: Chemical composition, dimensions, geometry, casting temperature, time from onset of solidification, heattransfer coefficient, surface temperature, spray pressure or water consumption, furnace heating cycle, furnace conditions, furnace tonnage, and others. Each of these variables must be measured or estimated and entered as data into the control computer. Therefore, the precision of the numerical solution is limited by the precision of the measured input data. Accuracy may be further diminished by the underlying assumption of the model, which may not predict periods of fluctuation in operating conditions.

Numerical modeling is a powerful tool for process control. Despite the existence of models that can predict the heat content or internal temperature profile of a body of hot steel, they do not replace the need for an accurate real-time measurement.

\section{Experimental Verification of Tenperature-Profile Models}

Most numerical models of internal temperature gradients are compared to experimentally measured values. The experimental techniques employed 
to monitor solidification kinetics include: the pour-out method, radioisotope tracers, and horizontal probing. For temperature gradients in both solid and solidifying steel, embedded thermocouples are widely used. With the exception of horizontal probing, each of these techniques is destructive.

In the pour-out method, molten metal is allowed to cool in a mold for a measured period of time, and then the relliaining liquid is poured out. This may be accomplished by inverting the mold or tapping the bottom of the ingot. Results of the pour-out technique are difficult to reproduce, except with pure metals, and are relatively inaccurate.

The tracer method involves periodic injection of radioactive ${ }^{(6)}$ isotopes into the liquid steel in either ingots or continuous castings $(7)$. The radioactivity becomes uniformly distributed throughout the remaining liquid. If the same isotope is used throughout, equal additions are made at regular intervals, resulting in solidified zones of progressively higher activity. The piece is usually sectioned and a photographic exposure made of the surface in a process called autoradiography. Alternatively, different isotopes could be used with each subsequent addition and the differences in their radioactive properties measured.

Horizontal probing is a nondestructive technique for nondestructively measuring the thickness of the solidified shell in ingots. The technique, as illustrated in Figure IV-3, uses simple geometry to convert the mechanical measurement into shell thickness. The maximum error is reported to be about 6 percent, although degradation of the probe and possible contamination of the melt are not mentioned. (8)

Embedded thermocouples can be used to monitor either solidification or the temperature of solids. For monitoring solidification, thermocouples are inserted at various points in the mold cavity, and the duration of thermal arrest is measured. However, the motion of the solidification front is difficult to reconstruct from a few points.

A new embedded-thermocouple system for use in slab-reheat furnaces is being sold commercially by Fedesco ${ }^{(9)}$. The system consists of embedded $\mathrm{NiCr}-\mathrm{Ni}$ thermocouples that are connected to an electronic monitor sealed in a specially designed insulating box that rides on top of the siab (Figure IV-4). The monitor is capable of storing up to 255 measurements 
in each of six channels during its voyage through the reheat furnace. After transit through the furnace, the monitor is removed. The monitor is then connnected to a strip-chart recorder that prints out the data. Bethlehem Steel, Inland Steel, Republic Steel, and Ford Motor Company have already purchased these systems. $(10)$

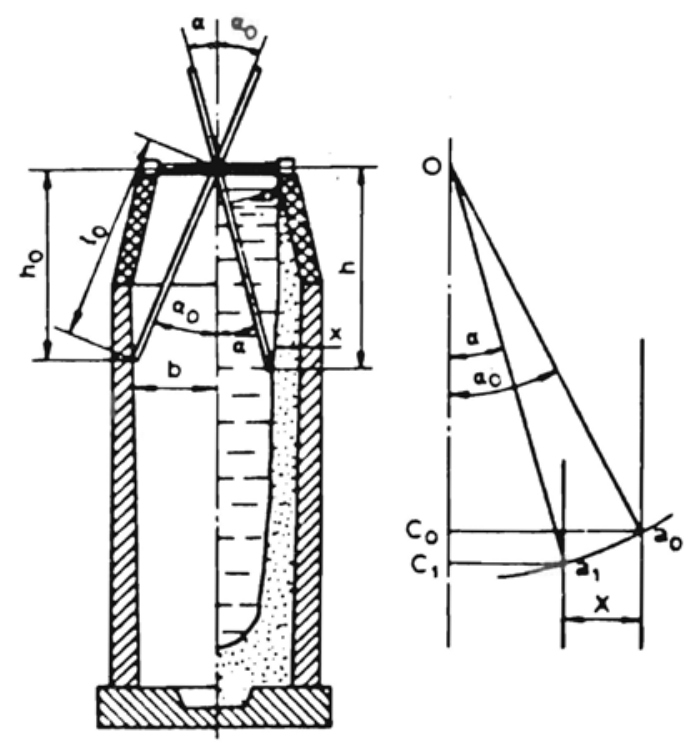

FIGURE IV-3. SCHEMATIC DIAGRAM OF HORIZONTAL PROBING TECHNIQUE (8)

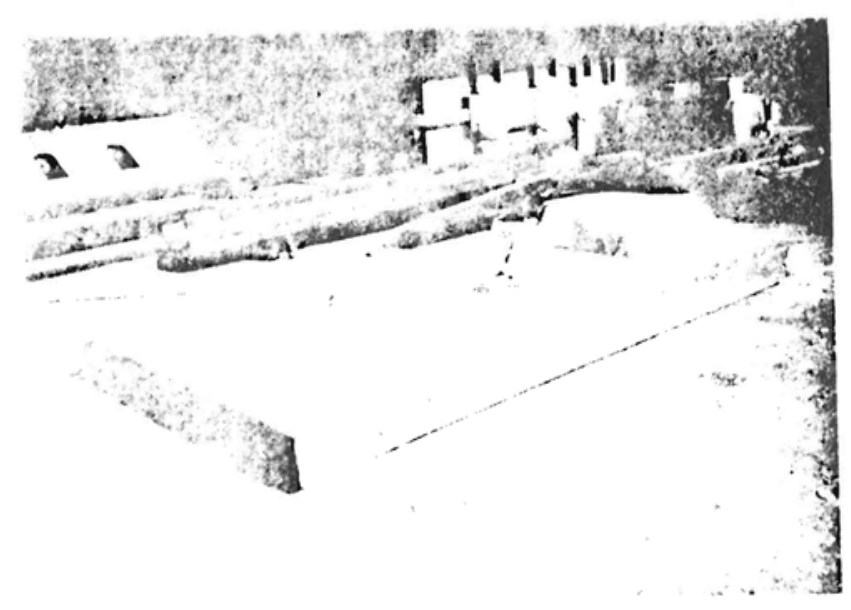

FIGURE IV-4. PHOTOGRAPH OF FEDESCO'S EMBEDDED THERMOCOUPLE SYSTEM MOUNTED ON A STEEL SLAB (9) 


\section{INTERNAL -TEMPERATURE MEASUREMENT}

Up to this point, the terms "thermal state", "temperature profile", and "temperature measurement" have been used loosely and interchangeably. Before proceeding to evaluate nondestructive testing methods, the objectives of a sensor-development program to measure internal temperatures in hot steel bodies need to be described in greater detail.

One can envision at least three categories of systemis (presented in probable order of increasing difficulty):

(1) Real-time measurement and location of the 1iquid/internal solid interface during solidification. Solidification of steel proceeds with cellutar or dendritic extensions of the solid into the liquid, giving rise to a zone comprised of both states. This is called the "mushy" zone (Figure $V-1$ ). Measuring the location of the mushy zone involves the measurement of a finite temperature range (solidus to liquidus).

(2) Real-time measurement of the average internal temperature or heat capacity of bulk solids. This might involve a temperature measurement integrated over the thickness at a single point, over a particular cross section, or over the entire volume of the solid. The magnitude of the temperature variation is not reflected by an average temperature measurement.

(3) Real-time measurement of internal-temperature distributions. This is the ultimate target and would be of greatest utility in steel production. The measured temperature distribution could be one, two, or three dimensional.

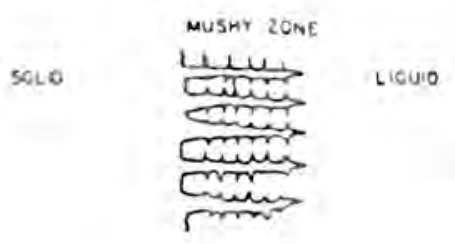

FIGURE V-1. SCHEMATIC OF "MUSHY ZONE" DURING STEEL SOLIDIFICATION (32) 


\section{Nondestructive Tests}

Measurement of the internal temperatures of hot solid steel bodies will require some method of nondestructive testing. A successful nondestructive test exhibits a number of fundamental characteristics. These include:

- A Probing Medium. A nondestructive test requires a probing medium. Usually this is some type of energy, be it electromagnetic radiations, sound energy, electrical, or mechanical. But it must be capable of transmission to the area of interest. In this case, to the center of the body of hot steel. Therefore, an energy transmission source is required.

- Modulation of the Probing Medium. The characteristic to be measured must alter or modulate the probing medium in some manner. This altered or changed probing medium must then be capable of exiting the inspected part with the information.

- Detection of the Modulated Probing Medium. In order to be able to record or otherwide measure the modulated signal, some detection method must be capable of recording the modulated signal. This signal may be amplified, or processed in other ways.

- Interpretation. The detected signal must be interpretable. This interpretation must be reliable to the extent that decisions can be made and acceptance/rejectance criteria established.

Note that "nondestructive" is not synonymous with "noncontact". A nondestructive contact system could be acceptable if it were capable of performing real-time measurement. In general, however, contacting probes are susceptible to high-temperature wear and erosion. For this reason, noncontacting systems are preferred.

\section{Identification of Possible Nondestructive Test Methods}

Many nondestructive tests do not directly measure the desired physical characteristics. Rather, measurement of some related phenomena is often used to obtain a result. For example, the internal temperature gradients of a body of hot steel can be measured directly with embedded thermocouples, but by sacrificing the piece being evaluated. A nonintrusive 
alternative might be a measurement of the temperature-dependent velocity of an acoustic wave in the solid. The velocity measurement would be translated to an internal temperature value by calibration. The velocity of sound in a solid is one of four temperature-dependent physical principles that have been identified for possible adaptation to internal temperature measurement. The other three include thermal expansion, neutron thermalization, and electrical conductivity.

\section{Velocity of Sound}

The velocity of acoustic waves in materials is a function of temperature. Conversely, the internal temperature of a material can be determined by measurement of the velocity of an internally transmitted acoustic wave. The relationship between acoustic velocity and temperature has been measured for several different steels (Figure $V-2$ ), cast iron (Figure $V-3$ ), and nonferrous pure metals (Figure $V-4$ ). The attenuation of a $0.5 \mathrm{MHz}$ signal with temperature from 0.47 percent carbon steel is shown in Figure $V-5$. If the temperature of a specimen is uniform, a single measurement of velocity is sufficient to obtain an internal temperature measurement. In steelmaking applications, temperature gradients do exist. Therefore, a single measurement of ultrasonic velocity would yield an average (integrated) temperature. To establish the internal-temperature depth profile, a complex series of velocity measurements must be made. The technique is called ultrasonic tomography. Ultrasonic tomography has been used in steels to map

residual stresses (15). But, to our knowledge, it has not been applied to temperature-gradient mapping.

Ultrasonic techniques are being developed to measure the solid/ liquid interface of steel during solidification. Nippon Steel has developed a system using noncontacting electromagnetic ultrasonic transducers (EMAT) for both transmission and retrieval of longitudinal 47 trasonic waves $(16,17)$. The EMATS were installed roughly 6 meters away from the mold on a continuous caster at Nippon's Yawata Works, as shown schematically in Figure $V-6$. The position of the ultrasonically measured solidification front was within 2 to 3 m of a directly (destructively) measured value (Figure $V-7$ ). According to Nippon representatives, their shell-thickness system is experimental, but ivippon does use an ultrasonic system in production to detect porosity in continuously cast slabs (18). 


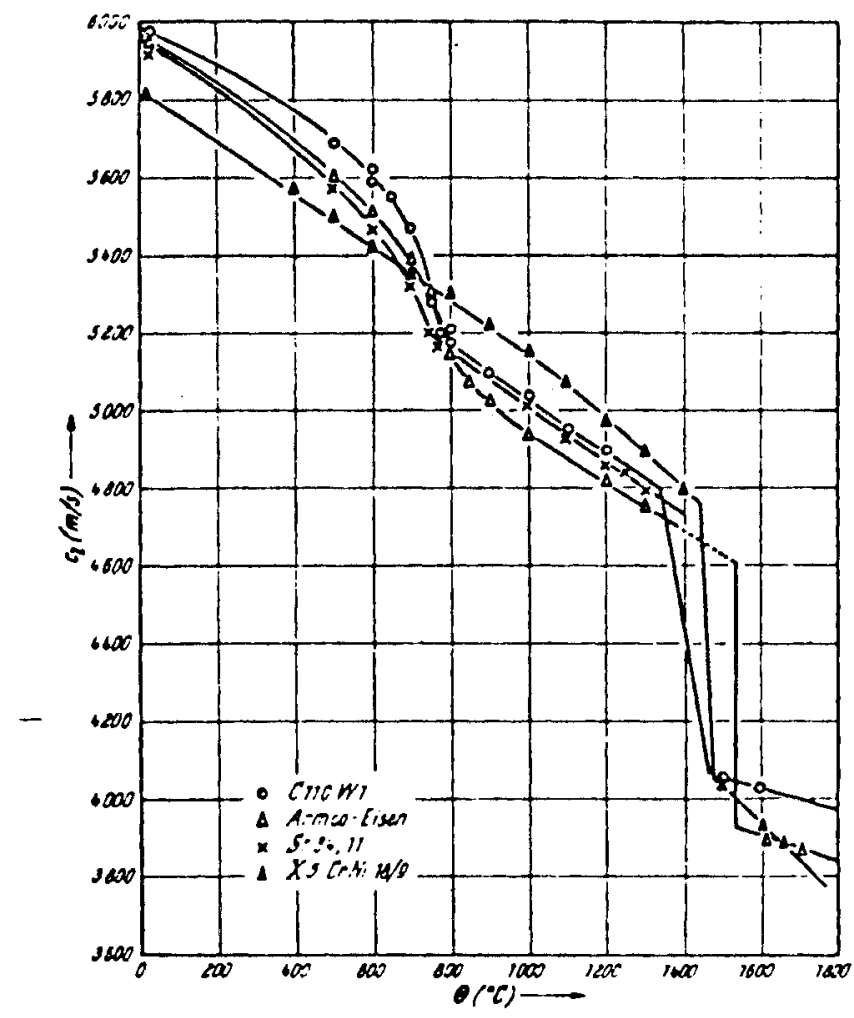

FIGURE V-2. LONGITUDINAL ULTRASONIC WAVE VELOCITY AS A FUNCTION OF TEMPERATURE FOR DIFFERENT STEELS (12) 


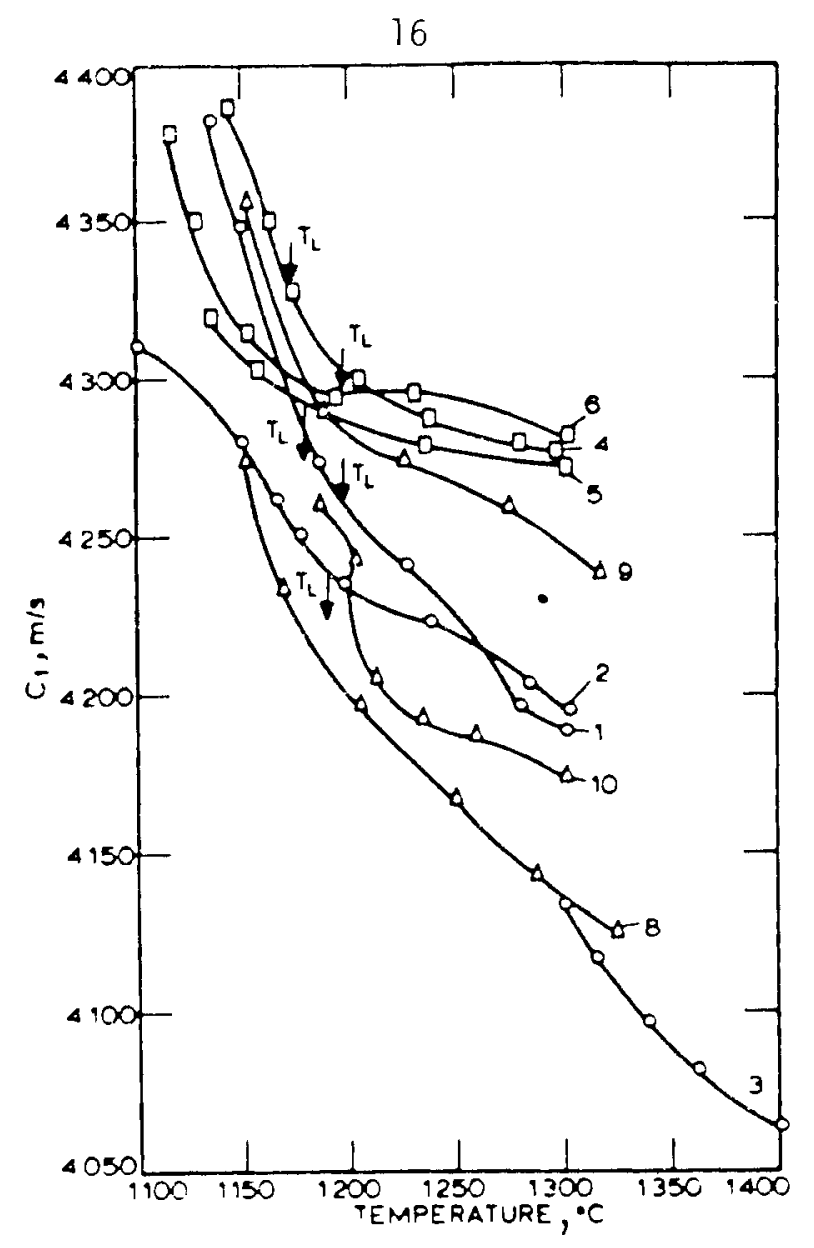

c. uninoculated, $=$, inoculated: $A$, alloyed

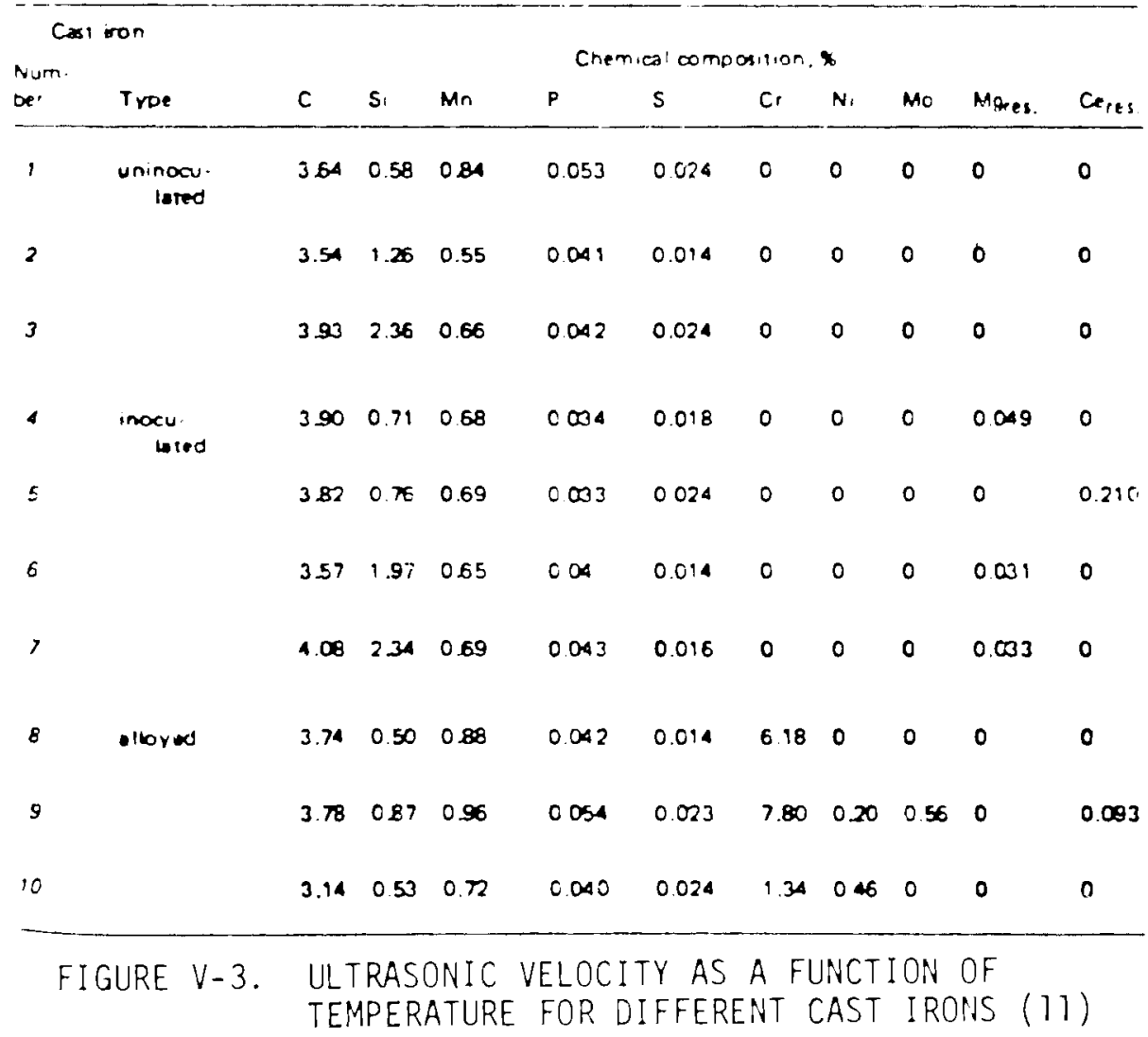




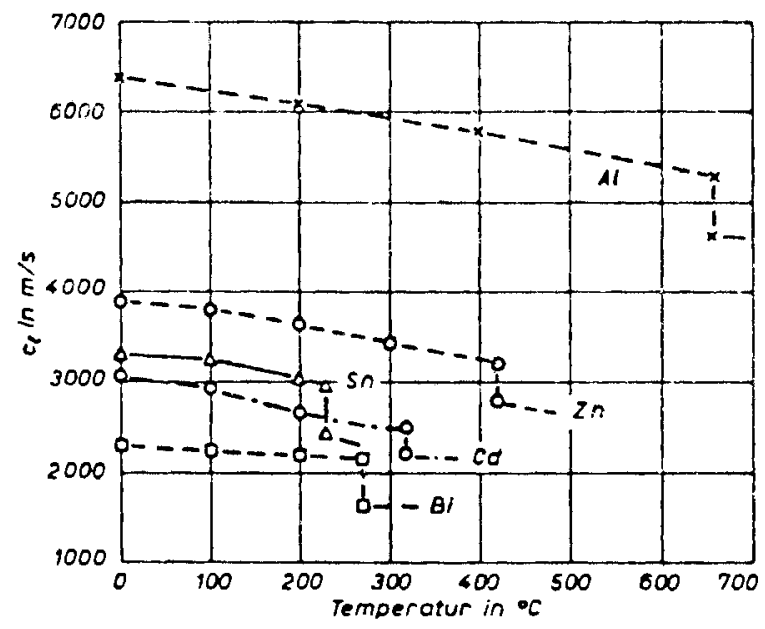

FIGURE V-4. VELOCITY OF LONGITUDINAL ULTRASONIC WAVES IN NON-FERROUS PURE METALS AS A FUNCTION OF TEMPERATURE (13)

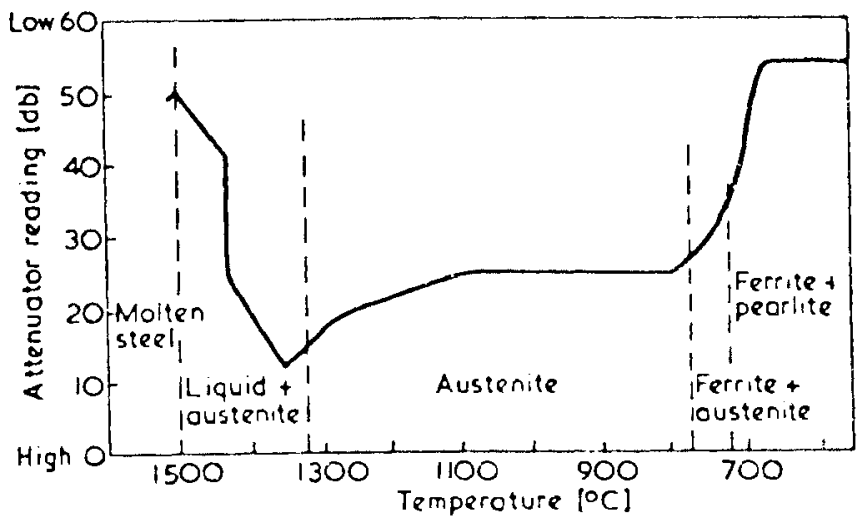

FIGURE $V-5$. ATTENUATION OF $0.5 \mathrm{MHZ}$ ULTRASONIC SIGNAL WITH TEMPERATURE FOR $0.47 \%$ CARBON STEEL (14) 


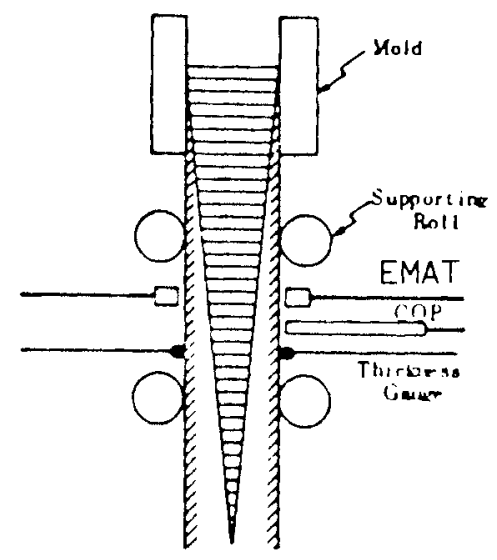

FIGURE $\forall-6$. SCHEMATIC OF NIPPON STEEL SYSTEM TO MEASURE SOLIDIFICATION SHELL THICKNESS IN CONTINUOUSLY CAST STEEL STRANDS (17)

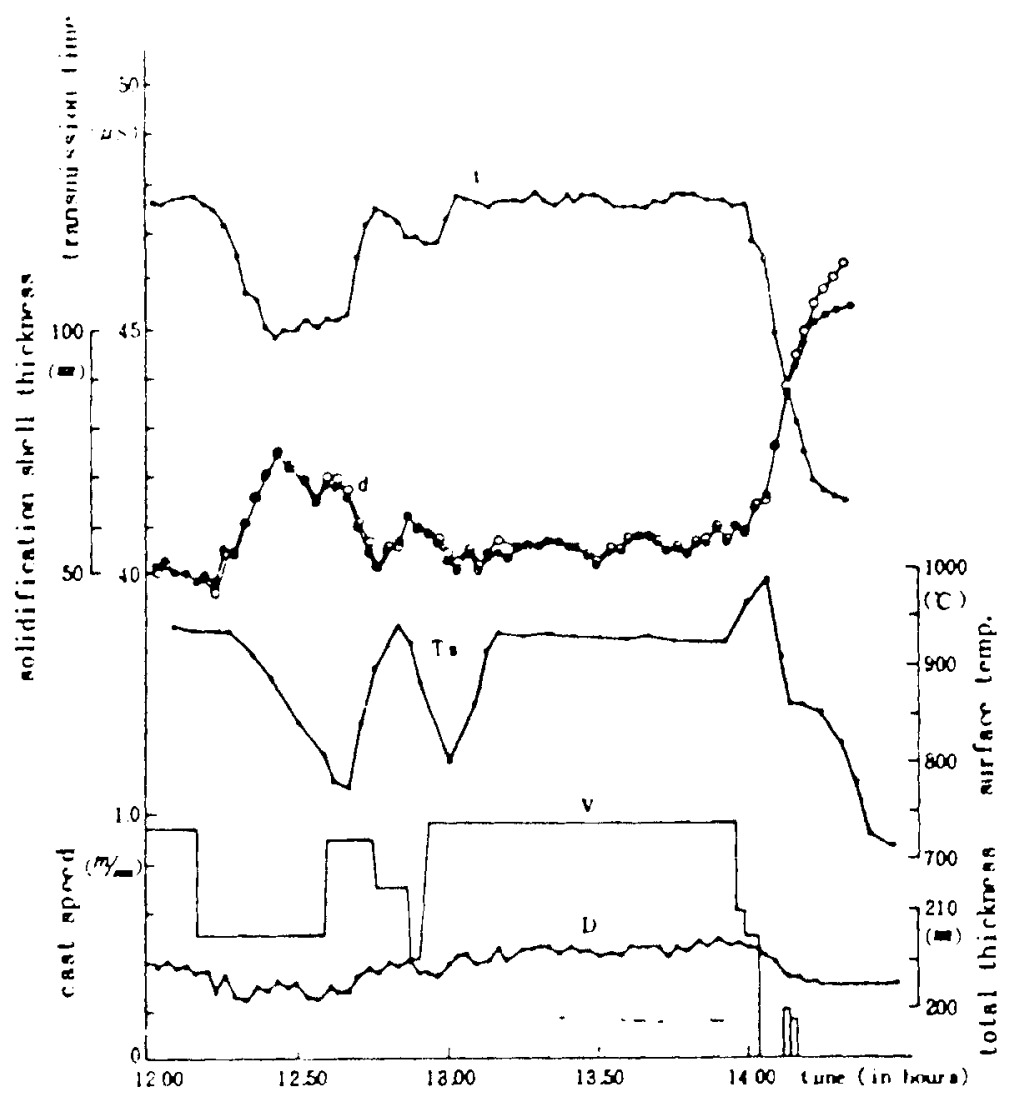

FIGUPE V-7. SOLIDIFICATION SHELL THICKNESS AND OTHER EXPERIMENTAL PARAMETERS MEASURED WITH NIPPON STEEL SYSTEM (17) 
Krautkramer GmBH in Cologne, West Germany, is developing laserinduced ultrasound to locate the solidification shell in continuously cast steel. The system will be installed and field-tested in German mills before it will be available commercially. A detailed description of the system or its capabilities has not been found in the published literature. In the early 1970's, work was conducted at the Timken Company in Canton, Dhio, investigating a momentary-contact conventional ultrasonic transducer that was developed at Panametrics, Inc. in Waltham, Massachusetts $(19,20)$. More recently, it has been rumored that Timken is developing a proprietary contacting ultrasonic technique for measuring the solidification-shell thickness of continuously cast steel. Attempts to obtain a confirmation or denial of this rumor from Timken were unsuccessful.

Alternatives to time-of-flight ultrasonic measurements have been suggested. If a quasi-continuous ultrasonic wave were used, the phase shift of the continuous wave might be used to monitor the internal temperature of the specimen. Another suggested approach is time-lapse measurement of the resonance of a solid specimen. The rimming action of steels during solidification has been characterized by acoustic measurements ${ }^{(21)}$.

Thermal Expansion/Density

Metals expand when heated and contract during cooling. For exalıple, the coefficient of linear expansion for steels is 6.7 in. $/$ in. $/{ }^{\circ} \mathrm{F}$. Thermal expansion can be determined directly by time-lapse measurements of dimensional changes during heating or cooling. Such measurements are affected by internal-temperature fluctuations. This technique is called dilatometry. It has been applied to measurement of the average temperature of steel billets and their enthalpy by researchers in the Soviet Union (22). It is not known whether the Soviet dilametric method for monitoring the temperature of steel in furnaces has been used industrially.

Laser-optic systems have been developed to be capable of dimensional measurements of distances as small as a fraction of a wavelength of light. An advantage of laser-optic systems compared to mechanical systems in dilatometric measurement is that no physical contact with the sample is required. Laser-optic systens can also scan large surface areas rapidly, 
suggesting the possibility of mapping the expansion of the surfaces in three dimensions. The internal-temperature profiles might be reconstructed from the surface-expansion profiles.

As the dimensions of a steel body increases during heating, the density decreases accordingly. Rather than measuring dimensional charges to determine internal temperatures, the density changes of the body could be measured. To this end, radiography has been used to penetrate steels of thicknesses of a foot or more. The absorption of radiation by matter is dependent on both density and thickness: measurement of one of the two parameters can be used to determine the other.

The Soviets have developed a radiographic system called FAZA-2 to measure the location of the solid/liquid interface in a continuously cast steel strand (23-25). The different densities of solid steel and of molten steel are measured experinentally $\left(7.8 \mathrm{~g} / \mathrm{cm}^{3}\right.$ and $7.2 \mathrm{~g} / \mathrm{cm}^{3}$, respectively). By fixing the densities, the solid-shell thickness can be calculated from radiographic measurements.

The FAZA-2 system consists of a cesium source of gamma radiation that is placed next to the continuous cast strand. Because the shell thickness may not be uniform on both sides of the strand, the transmitted and backscattered radiation flux are measured separately by two cesium detectors (Figure $V-8$ ). The solid-shell thickness on each side of the strand can be calculated, with the aid of a computer.

The FAZA-2 device has been used on a $70 \mathrm{~mm} \times 300 \mathrm{~mm}$ continuous casting machine at the Azovstal Steel Works in Zhdanov, USSR. During operation, the mean square error does not exceed 0.7 to 0.8 mn. At casting rates of 1.5 to $2.5 \mathrm{~m} / \mathrm{min}$, the time $\mathrm{lag}$ for the system is reported to be less than 0.4 second. It is reported that breakouts are avoided and billet quality is improved as a direct result of measurements taken by the FAZA-2 system.

Scientific Measurements Systems (SMS), Austin, Texas is developing gamma tomographic systems to detect slag inclusions, delaminations, and to determine internal-temperature profiles in hot steel billets with liquid centers. The systems will be sold commercially to private steel companies. A complex series of gamma transmission measurements at differing orientations with respect to the billet are fed into a computer. The computer uses an algorithm to reconstruct the interior structural density of the billet. With 


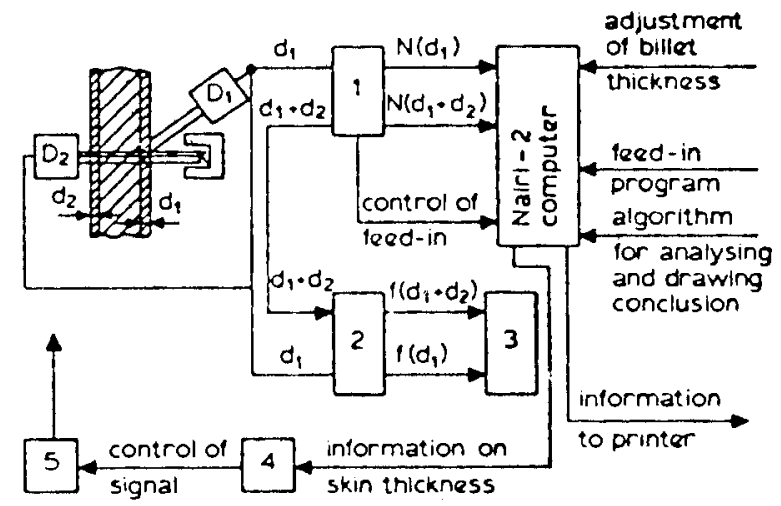

1. unit for preliminary analysis of discrete information; 2, unit for analysing analog information; $3, N-327 / 3$ recording unit; 4, unit for controlling withdrawal mechanism; 5, withdrawal speed regulator; for other explanations, see text

FIGURE $V-8$. SCHEMATIC OF SOVIET FAZA-2 SYSTEM FOR MEASURING SOLIDIFICATION SHELL THICKNESS (25) 
calibration, the density profile can be converted to an internal-temperature profile plotted at $20 \mathrm{C}$ intervals and projected in a television-like image.

Neutron Thermalization

Energetic neutrons injected into a material collide with the surrounding atoms as they propogate through the specimen. These collisions reduce the kinetic energy of the neutrons until they reach thermal equilibrium with the atoms in the specimen. Some of the neutrons are absorbed, but many more will be transmitted. The energy distribution of transmitted neutrons can be measured and can be related to the energy of the atoms that make up the sample. The energy of the atoms is, in turn, directly related to the temperature of the specimens. With calibration, it is possible to obtain a weighted average internal-temperature measurement.

The absorption of neutrons in a given sample depends on the chemical composition of the material. The neutron-capture cross section is a measure of absorption (in barns) which varies irregularly with the atomic weight of the element.

A prototype neutron-thermalization system was developed at IRT Corporation in San Diego, California, under DOE sponsorship $(26,27)$. The neutron sensor was intended to be used for geothermal-well logging, but might be used to measure the internal temperature of steel. A Californium-252 source of fast neutrons is placed next to the specimen. The emitted neutrons enter the specimen and transfer their energy during collisions with the neutrons in the material. The thermalized neutrons emerge from the specimen and are counted by detectors that are sensitive to different energy ranges. The average temperature of the specimen is reconstructed from the measured energy of the therinalized neutrons.

\section{Electrical Conductivity}

The electrical conductivity/resistivity of a conductor varies with temperature. The relationship between resistivity and temperature for an iron standard is shown in Figure $V-9$. By measurement of the conductivity 


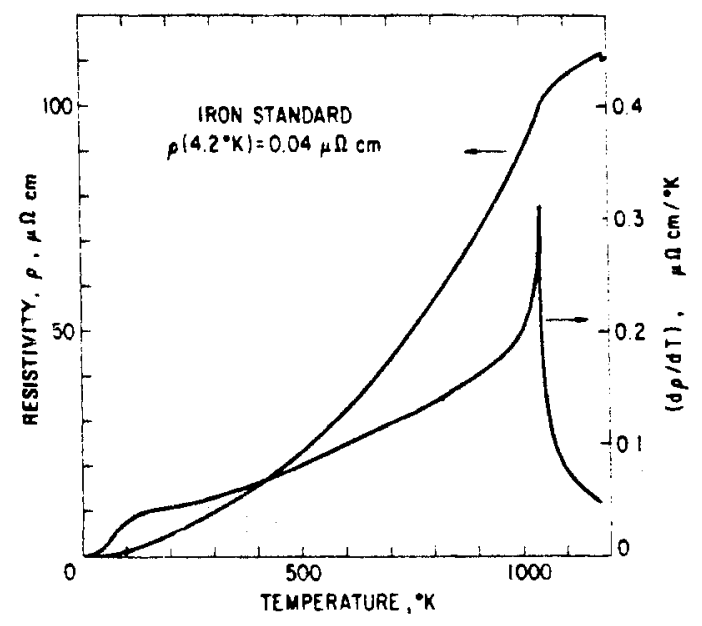

FIGURE V-9. RESISTIVITY AND FIRST DERIVITIVE $\mathrm{d}_{\rho} / \mathrm{dT}$ OF AN IRON STANDARD WITH TEMPERATURE (28) 
or resistivity of a hot steel body at various depths, the temperature gradients might be reconstructed.

Iron and steels are ferromagnetic, with a Curie point at roughly $7420 \mathrm{~F}$ for pure iron. Magnetic permeability might affect conductivity measurements taken below the Curie point in steels. Permeability varies with temperature below the Curie point. Permeability measurements might be lised in place of or in addition to conductivity measurements to reconstruct internal-temperature profiles below the Curie point.

Several different eddy-current techniques for temperature measurement have been described in the literature. Most examine surface temperatures, although researchers have applied eddy-current methods to monitor solidification $(29,30)$ and internal-temperature gradients in nonmagnetic metals $(31)$. These techniques might be adpated to monitor the solidification and internal temperatures of steel above the curie point.

Since 1970, researchers at the University of Minnesota have been characterizing materials at elevated temperatures using eddy-current techniques. They have developed systematic techniques for interpreting eddycurrent data and producing profiles of electrical conductivity. From a conductivity profile, internal-temperature profiles can be determined, irternal flaws detected, and solidifying regions located and characterized $(32,33)$.

An eddy-current inspection system was installed on a billet caster at North Star Steel in Saint Paul, Minnesota (Figure V-10). The strand was stopped and allowed to cool. The cooling of the strand and mold could be detected, as well as the ferromagnetic transformation of the strand skin. During casting, a breakout was detected from eddy-current signals. The average mold temperature was determined by calibration from laboratory measurements with an empty mold. Because the coils were placed around the mold, the mold became a factor in the measurements. Measurements taken below the mold might yield more information about solidification.

A new business enterprise, called Castings Analysis, Inc., will be formed in June 1982 to adapt the eddy-current techniques developed at the University of Minnesota to industrial problems. Castings Analysis will be a subsidiary of Magnetic Analysis, Inc. of Mount Vernon, New York, and will be staffed by researchers from the University of Minnesota. Information concerning Castings Analysis' products and services was unavailable before 


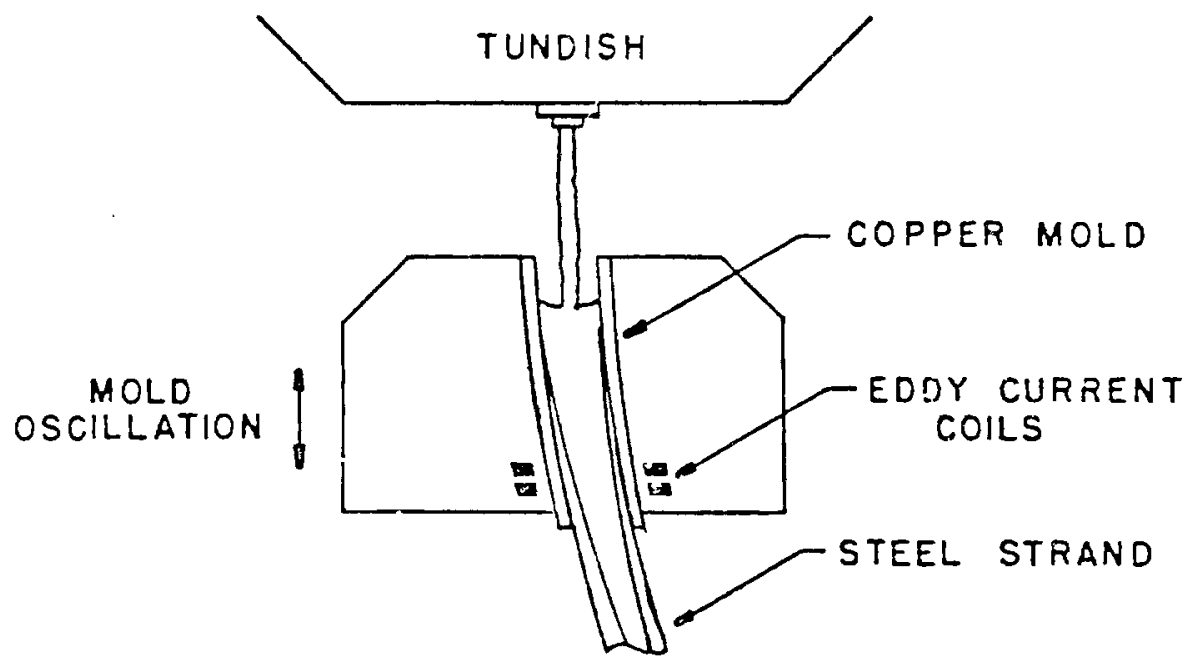

FIGURE $V$ - 10 . SCHEMATIC OF COIL PLACEMENT IN MOLD OF

CONTINUOUS CASTING MACHINE AT NORTH STAR STEEL (33) 
the date of publication of this report. However, they are discussing temperature-gradient mapping systems with aluminum and steel company executives.

\section{UTILITY OF THERMAL-PROFILE SENSOR IN EXISTING FACILITIES}

If a thermal-profile sensor were developed, it would have immediate application in existing steelmaking facilities. This was established without question by the practically unanimous opinion of knowledgeable management and operating personnel in the steel industry, and by their encouragement and involvement in efforts to develop such a sensor.

In terms of total energy consumption, the three most energyintensive operations to which the sensor might be applied are:

- Continuous casting

- Ingot production and breakdown

- Reheat furnaces.

As will be shown, the potential savings to be expected from wide implementation of a thermal-profile sensor are about as follows:

\begin{tabular}{|c|c|c|c|}
\hline Continuous & $\begin{array}{l}\text { Ingot } \\
\text { Production } \\
\text { and }\end{array}$ & Reheat & \\
\hline Casting & Breakdown & Furnaces & Total \\
\hline
\end{tabular}

Tonnage basis, $10^{6}$ tons/yr $\quad 41.2 \quad 116.6 \quad 120.0 \quad$-.Potential Savings:

$\begin{array}{lrrrc}\text { Total, 1012 Btu/yr } & 79.2 & 22.8 & 35.1 & 77.1 \\ \text { Specific, 106 Btu/ton } & 0.5 & 0.2 & 0.3 & -- \\ \$ \text { Millions/yr } & \$ 77 & \$ 91 & \$ 140 & \$ 308 .\end{array}$

There are many other steelmaking operations that stand to benefit from internal temperature-profile measurement. These include, but are not limited to, castings, batch annealing furnaces, and furnaces used in the production of forgings, tubular products, structural products, and coated products. Non-steelmaking applications might include measurement of internal temperature during metal extrusion, ceramics production, operation of fluidized beds, power generation, and other industrial applications. 
It is possible, but improbable, that one universal nonintrusive sensor might be developed to satisfy the diversity of needs for know]edge of the internal temperature profile of a solid or semi-solid body. Therefore, the ultimate development is likely to consist of a family of sensors, perhaps a11 based on one general principle. Although the potential applications may be varied and diverse, this discussion will focus on the three potential applications in steelmaking judged to have the hignest energy-saving opportunities.

\section{Continuous Casting}

The high melting point, low thermal conductivity, and high specific heat of steel serve to limit heat transfer during continuous casting. This contributes to retention of molten steel in the interior of the continuously cast strand for some distance beyond the mold. During continuous casting, solidification of steel occurs over a much greater distance beyond the mold than with aluminum (Figure VI- 7 ).

In the mold, if the solidified shell does not have sufficient strength to contain the molten metal, a rupture will occur, resuiting in a "breakout". Similarly, molten steel present during cucting of a sirand results in a "runout". In vertical-bending types of casters, a moiten steel center in the bending region may lead to centerline cracking. Measurement of the thermal gradients in the continuously cast strand would provide additional means to alleviate these problems.

Computer control of continuous casters is difficuit to impiement because the casting rate changes frequentiy and seconaary cooling rates also vary. Real-time measurement of the temperature profile would make possible a significant advancement toward computer control of continuous casting. Therefore, it is not surprising that most of the nondestructive techniques identified in the previous section are being field-tested first on casters.

Surface-temperature measurements aside, many efforts are underway to measure internal phenomena. In an attempt to locate the solidification front, Nippon Steel, Tokyo, Japan, is deveioping an uitrasonic system using noncontacting EMAT's. Krautkramer of Coiogne, West Germany, is ceveloping a laser-inauced uitrasonic system. There are unverified rumors that Timken Company, Canton, Ohio, USA, is developing contacting ultrasonic systems. 


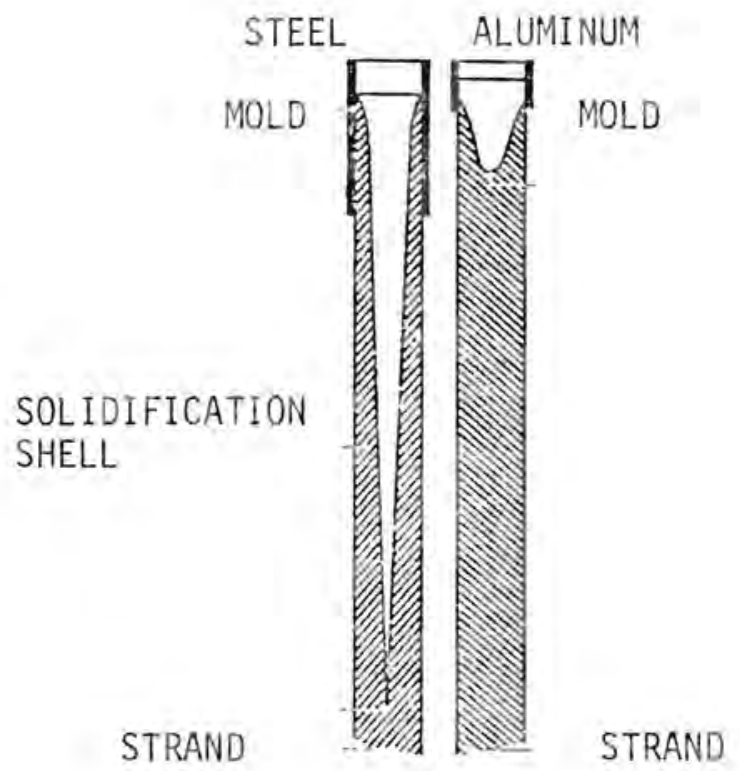

FIGURE VI-1. SCHEMATIC OF SOLIDIFICATION OF STEEL AND ALUMINUM DURING CONTINUOUS CASTING (12) 
The Soviets claim to have developed a gamma-attentuation technique to locate the solidification front. A new company called Castings Analysis, Mount Vernon, New York, will design and build eddy-current systems to monitor solidification and possibly to construct internal-temperature profiles of steel and nonferrous metals during solidification. Scientific Measurement Systems, Austin, Texas, claims to be building a tomographic system, using gamma-transmission measurements that can determine internal temperature gradients and project them in a TV-type image.

The environment to which these measurement devices will be subjected is severe. Surface temperatures range from 1200 to $2600 \mathrm{~F}$ on the strand. A real-time measurement may involve a few minutes, but a measurement on the order of seconds is preferable. Internally, there may be porosity, chemical segregation, and molten steel. Externally, an oxide scale exists along with water and steam.

Let's assume that a suitable device becomes available for all types of continuous casters. How much energy could be saved following industry-wide adoption of a temperature-gradient mapping system? Both direct and indirect energy savings can be identified.

Knowledge of the internal temperature profile would allow casters to be operated at higher rates. Presently, casters are operated conservatively to avoid breakout and runout. Measurement of the thermal state would allow casting speeds to be increased by an estimated 10 percent. This represents additional continuous casting capacity of 4.2 million tons annually at a saving of about $1.4 \times 10^{6}$ Btu/ton when compared with ingot practice. Therefore, a total potential energy savings from increased capacity of existing continuous casters is estimated to be about $5.8 \times 10^{12}$ Btu/yr.

As previously mentioned, the problems of breakout, runout, and centerline cracking could be alleviated through measurement of internal temperature gradients. It is estimated that yield improvements of up to 1.5 percent are possible, with corresponding increases in overall energy efficiency. The total potential energy saving from yield improvements is estimated at $13.4 \times 10^{12}$ Btu/yr. 
When combined, the potential direct and indirect energy savings total $19.2 \times 10^{12}$ Btu/year $\left(0.5 \times 10^{6} \mathrm{Btu} /\right.$ ton $)$ for temperature-distribution mapping during continuous castint (Table VI-1). In addition, measurement of temperature distributions could be used to control solidification and solid-state cooling. The potential results is higher metallurgical quality with greater freedom to continuously cast steels that are currently considered too difficult to cast. The impact that the sensing device might have on continuous casting technology in the future will be discussed in Section VII.

The estimates of potential energy savings as presented in Table VI-1 are based on industry-wide adoption of measured temperature distributions. In reality, how might the steel industry respond? This is examined in four different categories related to the capacity of the casters currently in use.

First, consider the case of casters that produce billets and rounds. Nation-wide, about 80 billet casters are installed or committed. (34) The number of strands per caster varies from one to six. The capacity ranges from 33,000 tons/strand/year to 188,000 tons/strand/year. The mean capacity is roughly 75,000 tons/strand/year.

It has been estimated (Table VI-1) that the total potential energy saving attributable to temperature-distribution mapping averages about $0.5 \times 10^{6} \mathrm{Btu} /$ ton/year for continuously cast products. This represents a saving of $38 \times 10^{9}$ Btu/year for a single strand operating at 75,000 ton/year. With current energy costs averaging roughly $\$ 4$ per million Btu, the benefit of a temperature-distribution measurement from energy savings alone is about $\$ 152,000 /$ year for an average billet strand. These calculations are given in Table VI-2.

Similarly, the benefit of real-time temperature-distribution measurements can be estimated for slab and bloom casters. The annual average capacities per strand vary much more for slab casters than for billet casters. Consequently, slab casters are classified into three categories: (1) less than 500,000 tons per year per strand, (2) more than 500,000 but less than 1 million tons per year per strand, and (3) more than 1 million tons per year per strand. This system of classification reduces the variance in the average potential energy saving per strand. The results are compiled in Table VI-3.

The average benefit of temperature-distribution measurement in slab casters is estimated to range from $\$ 500,000$ per strand per year to $\$ 3$ million per strand per year. As the benefit increases, the number of facilities that 
TABLE VI-1. ANNUAL POTENTIAL ENERGY SAVINGS FROM MEASUREMENT

OF THERMAL STATE IN CONTINUOUS CASTERS

Type of Steel Plant

Integrated Scrap Based Specialty Total Installed/commited C.C.
capacity, $10^{6}$ tons/yr (34)
Potential increase in C.C.
capacity, $10^{6}$ tons/yr
Potential energy savings from
increased C.C. capacity,
$10^{12} \mathrm{Btu} / \mathrm{yr}$ (35)
Potential Capacity,
$10^{6}$ tons/yr
Estimated energy consumption,
$10^{12} \mathrm{Btu} / \mathrm{yr}$

Potential energy savings through yield improvements from measured temperature profile, $10^{12} \mathrm{Btu} / \mathrm{yr}$

$$
\varepsilon^{\star}=0.015
$$

Total potential annual

savings, $1012 \mathrm{Btu}$

Specific potential energy saying per unit capacity, $10^{6} \mathrm{Btu} /$ ton
22.7

16.0

2.5

2.3

1.6

0.3

3.2

2.2

0.4 5.8

25.0

17.6

2.8 45.4

495.0

348.0

55.0

898.0

41.2

\section{2}




\section{TABLE VI-2. CONTINUOUSLY CAST ROUNDS AND BILLETS}

Average annual capacity (per strand)

Number of casting machines

Number of strands
75,000 tpy

80

263

Potential average energy saving per strand

$(75,000)\left(0.5 \times 10^{6}\right)=38 \times 10^{9} \mathrm{Btu} / \mathrm{strand} /$ year

Average benefit*

$\left(38 \times 10^{9}\right)\left(4 \times 10^{-6}\right)=\$ 152,000 /$ strand $/$ year .

* Based on average cost of $\$ 4$ per million Btu.

TABLE VI-3. CONTINUOUSLY CAST BLOONS AND CLABS, ANNUAL CAPACITY RANGE ( $C$ in tons per year)

$$
\underline{C<500,000} 500,000<C<1,000,000 \quad C>1,000,000
$$

Average capacity per strand, tons/year

Number of casting machines

Number of strands

$$
250,000
$$

14

22

Average energy saving per strand, 1012 Btu/year

Average benefit, per strand/year*
0.13

0.38

0.75

$\$ 500,000$

$\$ 7,500,000$

$\$ 3,000,000$

* Based on average cost of $\$ 4$ per million Btu. 
coilu afford a gradient-mapping system diminishes. However, even the short-range benefits are considered large enough to justify a substantial development program.

\section{Ingct Production and Breakdown}

There has beer less interest in developing sensors to monitor internal temperatures during ingot production and breakdown than during continuous casting. In fact, only one study involving ingot solidification was found. The investigators developed an acoustic technique to monitor the rimming action(21).

Measurement of their internal-temperature profiles would al low ingots to be optimally stripped and charged hotter to soaking pits. Because the heating of the ingots in the soaking pits could be optimized, fuel consumption would decrease accordingly. This would result in ingots of more uniform temperature during breakdown. It is anticipated that the soaking time could be shortened, leading to reductions in fuel consumption, the operation of fewer furnaces, and extended furnace life. Optimization of ingot soaking would minimize formation of excess scale, thereby increasing yield.

The yield during ingot breakdown is also anticipated to be capabie of improvement because of measurements of the internal-temperature profile. Temperature and pressure are the two major variables during deformation. Internal-temperature measurement would allow more precise calculation of deformation parameters. As a result, it is anticipated that roll wear and roll breakage would be significantly reduced and overall yield improved.

It is estimated that up to 15 percent. of the fue 1 consumed in soaking pits could be conserved by knowledge of the thermal state of solid ingots during charging. Most ingots are hot charged. But the quantity of heat contained therein may vary greatiy, depending on the time elapsed from teeming and stripping. Measurement of the thermal state would lead to optimization of soaking-pit heating cycles for the worst-case ingot in the lot. The total potential energy saving from reduced fuel consumption. soaking pits is estimated to be about $19 \times 10^{6}$ million Btu per year (Table VI-4). 
TABLE VI-4. POTENTIAL ENERGY SAVING FROM MEASUREMENT OF THERMAL STATE IN SOAKING PITS AND BREAKDOWN MILL

Tota 1

Soaking pits:

Charging temp, ${ }^{\circ} \mathrm{F}(36)$

$77 \quad 1400 \quad 1600$

Annual production, $10^{6}$ tons/year (36)

11.7

46.6

$58.3 \quad 116.6$

Annual energy required, 1012 Btu/year (36)

42.28

75.52

67.34

182.10

Estimated potential energy savings

from reduced fuel consumption in soaking pit furnaces, $10^{12}$ Btu/year *

$\begin{array}{rlllll}\varepsilon^{*}= & 0.05 & 0.2 & 0.4 & 0.3 & \\ \varepsilon= & 0.10 & 3.0 & 5.1 & 4.7 & \\ \varepsilon= & 0.15 & \underline{1.3} & 2.2 & 2.0 & \\ & \text { Subtotals } & \overline{4.5} & \overline{7.7} & \overline{7.0} & 19.2\end{array}$

Potential energy savings from yield improvements,

$10^{12}$ Btu/year*

$$
\begin{aligned}
& \varepsilon^{\star *}=0.01 \\
& \varepsilon=0.02 \\
& \varepsilon=0.03
\end{aligned}
$$

\begin{tabular}{lll}
.1 & .1 & .1 \\
.5 & .9 & .8 \\
.3 & .4 & .4 \\
\hline .9 & $\frac{.4}{1.4}$ & $\frac{1.3}{1.4}$
\end{tabular}

3.6

Tota]
10
12
Btu

Specific potential energy savings, $10^{6} \mathrm{Btu} /$ ton/year

* Based on frequency distribution of estimated potential energy savings ** $\varepsilon=$ individual estimates of poiential energy savings 
Optimization of the reheating of ingots and measurement of their thermal state before hot breakdown is estimated to result in up to 3 percent improvement in yield during hot breakdown. Yield improvements arise from elimination of excessive scale, improved quality, and greater dimensional control. In addition, roll life and productivity would also be extended. The total potential energy saving from yield improvements is estimated to be $3.6 \times 10^{12}$ Btu/year.

The total potential energy saving from measurement of the internal temperature gradient is estimated to be $22.8 \times 10^{12}$ Btu/year for ingot production and breakdown. This represents an average saving of 0.2 million Btu per ton of charged product. (Table VI-4.)

It has been estimated that there are more than 2,500 soaking pit furnaces in the United States with a total reheat capacity of 185 million tons annua $77 y^{(37)}$. Therefore, the average capacity for a single soaking pit is 74,000 tons per year. The estimated potential energy saving per soaking pit is roughly $15 \times 10^{9} \mathrm{Btu} /$ year, based on our estimate of a savings of $0.2 \times 10^{6}$ per ton of annual capacity. Assuming that energy costs $\$ 4$ per million Btu, the estimated benefit of internal-temperature profile measurement on a single soaking pit furnace is roughly $\$ 60,000$ per year. In modern integrated steel mills, the average soaking pit capacity is in the 150,000 tpy to 200,000 tpy range, representing a utility of $\$ 120,000$ to $\$ 160,000$ per furnace.

\section{Reheat Furnaces}

There are many different types and sizes of furnaces for heating billets, rounds, slabs, forgings, etc. This discussion will focus primarily on slab-reheat furnaces used in hot-strip mills and plate mills. Slabreheat furnaces are among the largest energy consumers in an integrated mill, consuming up to about 3 million Btu per ton of steel.

Slab-reheat furnaces operate in several different stages, including preheat, heating, and soaking. The rolling mill's productive capacity is usually limited by either heating capacity or rolling capacity for the product size rolled. Furnace control and scheduling are, therefore, essential to increase the energy efficiency of the mill.

There have been many attempts to model the heating of billets and slabs in reheat furnaces. With a good model, it is possible to reduce fuel consumption and maintain hot steel ready while increasing yield. For model verification, Fedesco's embedded-thermocouple system is beginning to be used 
for both model verification and regular monitoring of reheat furnaces in several major American mills.

A model, no matter how sophisticated, does not take the place of an accurate measurement of internal-temperature profile. Models must be updated regularly to take into account changing furnace conditions. A measurement of internal-temperature gradient reduces uncertainty, allowing tighter control.

Lowering of fuel consumption by up to 15 percent is estimated to be possible because of measurement of the thermal state of pieces in reheating furnaces. Direct energy savings through reductions in fuel consumption would be supplemented by indirect energy savings because of increased furnace life, reduced furnace maintenance, and shorter cycle time. Potential energy saving from lower fuel consumption in reheating furnaces is estimated to total about $29.4 \times 10^{12}$ Btu/year. See Table VI-5.

There is also a potential energy saving through increased yield of plate and strip mills. It is estimated that yield improvements of up to 3 percent could result from measurement of internal temperature gradients. The potential energy saving from yield improvements is estimated to amount to 5.7 million Btu/year.

The total potential energy saving from nation-wide application of temperature-gradient measurements to reheat furnaces and associated roliing operations is estimated as about $35 \times 10^{12}$ Btu per year. The total potential energy saving appears to be greater for reheat furnaces than for continuous casters. However, note that the average potential energy saving per ton of rated capacity is higher for continuous casting than for reheat furnaces.

The relative utility of internal temperature-gradient measurements might be estimated from the costs of existing commercial systems. Equipment for Fedesco's system of embedded thermocouples costs between roughly $\$ 20,000$ and $\$ 40,000$ as of May 1982, depending on the options selected. The cost of the measurement is actually much higher because of costs associated with preparing and scrapping the test slab.

Alternatively, the utility of an internal temperature-gradient measurement can be estimated from the average potential energy saving found in Table VI-5. A large slab reheat furnace has a capacity of roughly 300 tons per hour. One eight-hour turn represents 2,400 tons. Muitiplying that by the average potential energy saving of $0.3 \mathrm{million} B$ tu/ton yields a saving of 720 million Btu per turn or $\$ 2,900$ per turn, assuming an energy cost of $\$ 4 / \mathrm{million}$ Btu. 
TABLE VI-5. POTENTIAL ENERGY SAVINGS FROM MEASURED THERMAL STATE IN REHEAT FURNACES AND ROLLING OPERATIONS

Charging temperature, ${ }^{\circ} \mathrm{F}(36)$

Annual production, $10^{6}$ tons/year (36)

120

Annual energy required, 1012 Btu/year (36)

280

Potential energy saving through reduced fuel consumption, * $10^{12} \mathrm{Btu} /$ year

$\begin{array}{rrr}\varepsilon^{\star \star}= & 0.05 & 1.4 \\ \varepsilon= & 0.10 & 19.6 \\ \varepsilon= & 0.15 & \frac{8.4}{29.4}\end{array}$

Potential energy saving through improved yield, $10^{12}$ Btu/year
$\varepsilon^{\star \star}=0.01$
0.6
$\varepsilon=0.02$
3.4
$\varepsilon=0.02$
1.7
Tota 1
5.7

Total potential energy saving, $1012 \mathrm{Btu} /$ year

35.1

Specific potential energy saving, 
If operating at high rate, e.g., 18 turns per week, 50 weeks per year, the total annual energy saving for a 300-ton-per-hour reheat furnace is estimated to be $0.65 \times 10^{12} \mathrm{Btu} /$ year; worth roughly $\$ 2.6 \mathrm{million} /$ year. This figure serves as an upper bound because relatively few reheat furnaces are in the 300-ton-per-hour class.

Average throughput for reheat furnaces is probably closer to 100 tons per hour. Multiplying the annual energy saving estimated above by one-third yields an annual energy savings per furnace of $0.22 \times 10^{12}$ Btu/year valued at $\$ 870,000$ per year.

The editors of 33 Metals Producing magazine surveyed the United States steel industry in 1978. Responses indicated there are about 103 reheat furnaces in hot rolling mills and 56 reheat furnaces in hot plate mills. The number of no-responses is roughly compensated by plant closings since 1978. Multiplying the number of slab reheating furnaces ( 160 ) by the average energy saving per furnace $\left(0.22 \times 10^{12}\right.$ Btu per year) yields $35.2 \times 10^{12}$ Btu/year, which checks with the total potential energy saving of $35.1 \times 10^{12}$ Btu/year, as calculated in Table VI-5.

\section{PROSPECTS IN NEW FACILITIES}

The implications of real-time measurement of the internal temperature profile of steel bodies are far-reaching. It may be too early realistically to assess the total impact that internal temperature measurements would have on steel production. However, the development of an internaltemperature sensor is expected to spur more widespread utilization of new energy-saving technologies. This discussion will focus on four technologies in particular:

\footnotetext{
- Direct rolling

- Liquid-Center Charging and Rolling

- Hot Charging

- Controlled Solidification.
} 


\section{Direct Rolling}

The principle of direct rolling is straightforward: the hot slabs produced by either continuous casting or ingot breakaown are rolled immediate1y in the hot mil1 without reheating (CC-DR and IC-DR in Figure VII-1). This eliminates the use of reheat furnaces. In North America, direct rolling has been adopted by a few "mini mi11s" and one integrated producer.

Real-time measurement of internal temperature would encourage greater use of direct rolling. The deformation of the steel during hot rolling could be controlled with greater certainty. Sorting based on the heat content of slabs could be used to avoid rolling slabs that have not retained sufficient heat.

The lack of internal temperature measurements does not represent the sole barrier of adopting direct-rolling technology. In many existing mills, the melt shop and hot mill are not in close proximity. In addition, surface-inspection techniques for detecting flaws in hot slabs and billets require further development.

The average energy consumption during slab reneating is estimated to vary from $1.5 \mathrm{million} \mathrm{Btu} /$ ton to $4 \mathrm{million} \mathrm{Btu/ton}$. Therefore, this approximates the potential energy saving attainable from direct rolling. A typical reheat furnace (100 tons per hour) operating at ful1 capacity (18 turns, 50 weeks) is estimated to use between $1.1 \times 10^{12} \mathrm{Btu}$ and $2.9 \times 10^{12} \mathrm{Btu} /$ year, costing an estimated $\$ 4$ million to $\$ 12$ million annually. Most hot strip mills are supplied from 2 to 5 reheat furnaces. Therefore, the total potential energy saving because of eliminating reheat furnaces by direct rolling is estimated to range from $2.2 \times 10^{12}$ to $14.5 \times 10^{12} \mathrm{Btu}$ per year for a single hot mill.

\section{Liquid-Center Charging and Rolling}

Some steel plants are saving energy by charging rimmed steel ingots into the soaking pits before the ingots are completely solidified. This practice is not new. However, Cook et al have refined the practice at ARMCO's Middletown (Ohio) Works, by the use of mathematical modeling, to a point where energy saving may have approached its potential maximum $(40)$. 


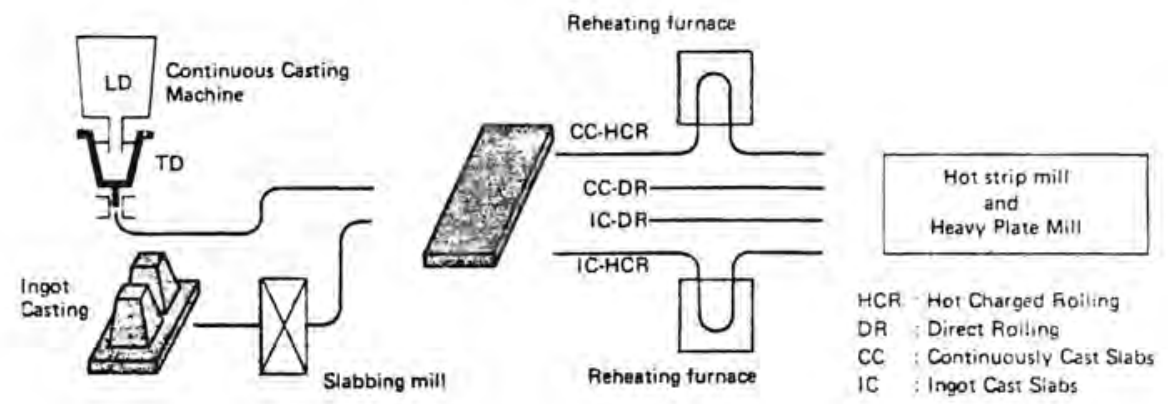

FIGURE VII-1. SCHEMATIC OF FLOW OF HOT-CHARGED DIRECT-ROLLING SYSTEMS (39) 
The model operates on a real-time basis as part of an integrated control system, and provides the basis for the ready-to-roll decision. The system takes into consideration the following variables:

- Time of teem of first and last ingot in a heat

- Pouring temperature

- Mold temperature

- Holding time in molds, which is based on the percentage of metal solidified

- Time required to strip ingots and charge to pits

- Soaking-pit temperature and time charged

- Breakdown-mill schedule.

Ingots can be charged while up to 50 percent of the ingot is still

liquid. Such ingots require little or no additional heat from the pit. Thus, the pit is used more as a temperature-equalizing furnace than as a heating furnace. Cook has found that there are optimum combinations in the multiplicity of stripping and charging times. If ingots are charged early enough, a delayed firing practice can be used which provides additional energy benefits and easier scheduling.

ARMCO's Middletown Works has adopted the practice of rolling rimmed ingots while their centers are still about 5 to 10 percent liquid. More than this amount causes the ingots to bulge during rolling.

The following advantages have accrued from the liquid-center charging and rolling development:

- The energy consumed in the soaking pit is $15 \%$ of that required during normal hot practice.

- Pit time has been shortened from 8 to 9 hours to 1.5 tc 3 hours.

- Mold life has been increased because of the shortened time that the ingots are left in the molds.

- Soaking-pit furnace linings last longer.

- Breakdown-mill roll life has been extended.

- Breakdown-mill yield on ingots has been increased.

- Breakdown-mil1 energy consumption has been decreased.

- Metallurgical quality improves. 
Possible Improvement by Use of Temperature-Profile Sensor

The computerized system developed by Cook et al reduces their urgency for deveioping a sensor that actually measures the temperature of an ingot throughout its cross section. Nevertheless, such a system would still be useful and contribute to further saving of energy. Thus, refinements probably could be made in Cook's computerized system if precise information could be obtained on (1) the amount of liquid metal in an ingot, (2) the average temperature of the ingots, and (3) the temperature profile througin the ingot. While it might not be necessary to have such information on every ingot, it would be desirable to check one or two ingots, perhaps the first and last poured, from every heat.

Furthermore, liquid charging and rolling has been applied only to rimming grades. The process has also been applied to semi-killed grades, but it may not be expedient to apply it to killed steels due to metallurgical limitations. Thus, a temperature-sensing system that would determine the precise moment at which killed steel ingots are sufficiently cool to be stripped would be desirable to establish metallurgical hold time and to confirm model projections.

\section{Hot Charging}

Hot charging refers to the practice of rapidly dispatching steel slais to the hot strip mill reheating furnance as soon as possible after they have been produced by the continuous casting process or from ingots in the slabbing mill. This is illustrated as flows CC-HCR and IC-HCR in Figure VIII-1. Hot charging differs from direct rolling in that direct rolling bypasses the reheating furnace.

In contrast, plants that do not use hot charging or direct rolling are obliged to charge into their reheating furnaces slabs that have been stored at room or outdoor temperature. This requires much more energy in the reheating furnace.

It was estimated earlier that direct rolling could save between $2.2 \times 10^{12}$ and $14.5 \times 10^{12}$ Btu/year for a single hot rolling mi11, depending on whether the mill used 2 or 5 reheat furnaces. With hot charging, less energy could be saved because the reheat furnaces are retained. The amount 
of energy saved by hot charging depends on the temperature and on the distribution of temperature of the slab when it is charged. A reasonable assumption is that about half as much energy could be saved in hot charging as in direct rolling, namely between $1.1 \times 10^{12}$ and $7.5 \times 10^{12}$ Btu/year for a single furnace.

Continuous Casting - Continuous Rolling Concept for Future Steel Plants

A limiting factor for energy saving when hot charging slabs from a continuous caster to a reheat furnace is the need to prevent runouts. The slab must be completely solidified before it is cut off from the rest of the strand. By the time the center has frozen, the outside surfaces of the slab, particularly the corners, are relatively cool.

A steel plant of advanced design can be visualized in which the cast strand enters an equalizing furnace while the center of the strand is still partly molten. Solidification is completed in the furnace. The residual heat in the strand makes it unnecessary to add much, if any, heat from the furnace. The strand is not cut into slabs until it leaves the equalizing furnace, at which point the slab enters directly into the hot strip mill.

In order to fill the capacity of the strip mi11, several strands would be fed into one or more equalizing furnaces, all serving the strip mill.

Internal temperature-gradient measurements would greatly facilitate the connection of the continuously cast strands to the hot rolling mill. The measurements could be used in control of the continuous casting machine, equalizing furnaces, slab cutting, and hot rolling mill operation. Elimination of defects and hot inspection of cast slabs will also be essential to any future continuous casting-continuous rolling plant.

\section{Controlled Solidification}

Real-time measurement of internal temperature gradients of steel during solidification may lead to revolutionary advances in process control. Continuous-casting technology, in particular, can be expected to benefit 
greatly. Continuous casters are controlled by metering the flow of molten steel through a tundish. If the internal temperature gradient were measured continuously, the caster could be controlled by continuous real-time monitoring of the solidification and secondary cooling of the strand. A higher level of controi of microstructure would be a beneficial result.

Continuous measurement of internal temperature gradients would allow the solidification growth rate to be monitored. The solidification rate could be controlled by varying the casting speed or by application of localized stirring. Not only could the quality of current continuously cast alloys be improved, but it might be possible to continuously cast a greater variety of alloys. Continuous casting might be extended to include alloys that are not now continuously cast because of segregation problems.

If the variety of steels that can be continuously cast is increased, this will encourage greater use of continuous casting over ingot metallurgy. Continuous casting saves an estimated 1.4 million Btu per ton compared to ingot practice. In addition, yield improvements and better quality control offer further energy-saving potential.

\section{RESEARCH RECOMMENDATIONS}

Before recommending specific research from a group of alternatives, it is appropriate to organize the results discussed in the previous sections of this report.

Three different categories of parameters have been identified. They are:

1. Measurement Goals

- Real-time measurement and location of the solid/ liquid interface of steel during solidification

- Real-time measurement of the average internal temperature of hot solid stee 7

- Real-time measurement of internal temperature distributions in bodies of hot steel.

2. Production Applications

- Continuous casting

- Ingot production and breakdown

- Reheat furnaces. 
3. Temperature-Dependent Physical Principles

- Thermal expansion/Density

- Acoustic veiocity

- Electrical conductivity

- Neutron thermalization.

A series of three matrices was prepared in which each parameter in each category was analyzed in combination with each parameter in each of the other two categories. Each element in each matrix (a total of 33 elements in the three matrices) was assigned one of four judgments as follows:

(A) The combination of the two parameters is reported to have been attempted.

(P) The combination of the two parameters may have potential, but has not reported to have been attempted.

(N) The two parameters are not related.

(D) The combination of the two parameters is reported to be under development.

The three matrices presented in Figures VIII-1 to VIII-3 show the nature of the relationships between applications and goals, between physical principles and applications, and between physical principles and goals. This system, however, does not take into account the magnitude of each activity. This will be discussed, specific to each measurement goal, in the recommendations to follow.

The following decision criteria were used to evaluate each of the measurement goals: "Any government-financed research and deveiopment activities will concentrate on lorig-term, high-risk, high potential payoff projects with the best chance for wide generic application to materials problems and increased productivity." (National Materials and Minerals Program Pian and Report to Congress, April 5, 1982) 


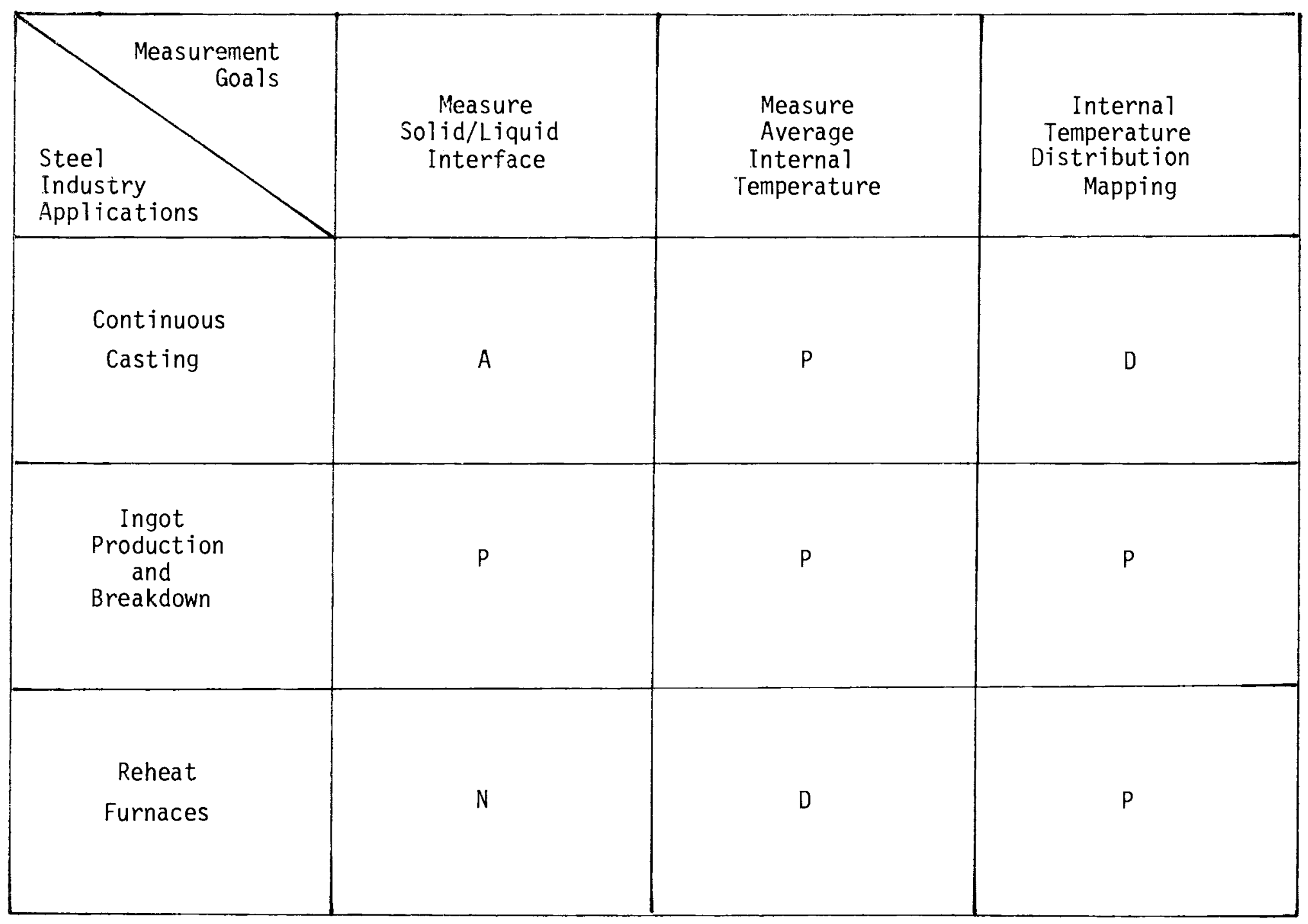

FIGURE VIII-1. RESEARCH MATRIX COHBINING MEASUREMENT GOALS WITH STEELINAKING APPLICATIONS 


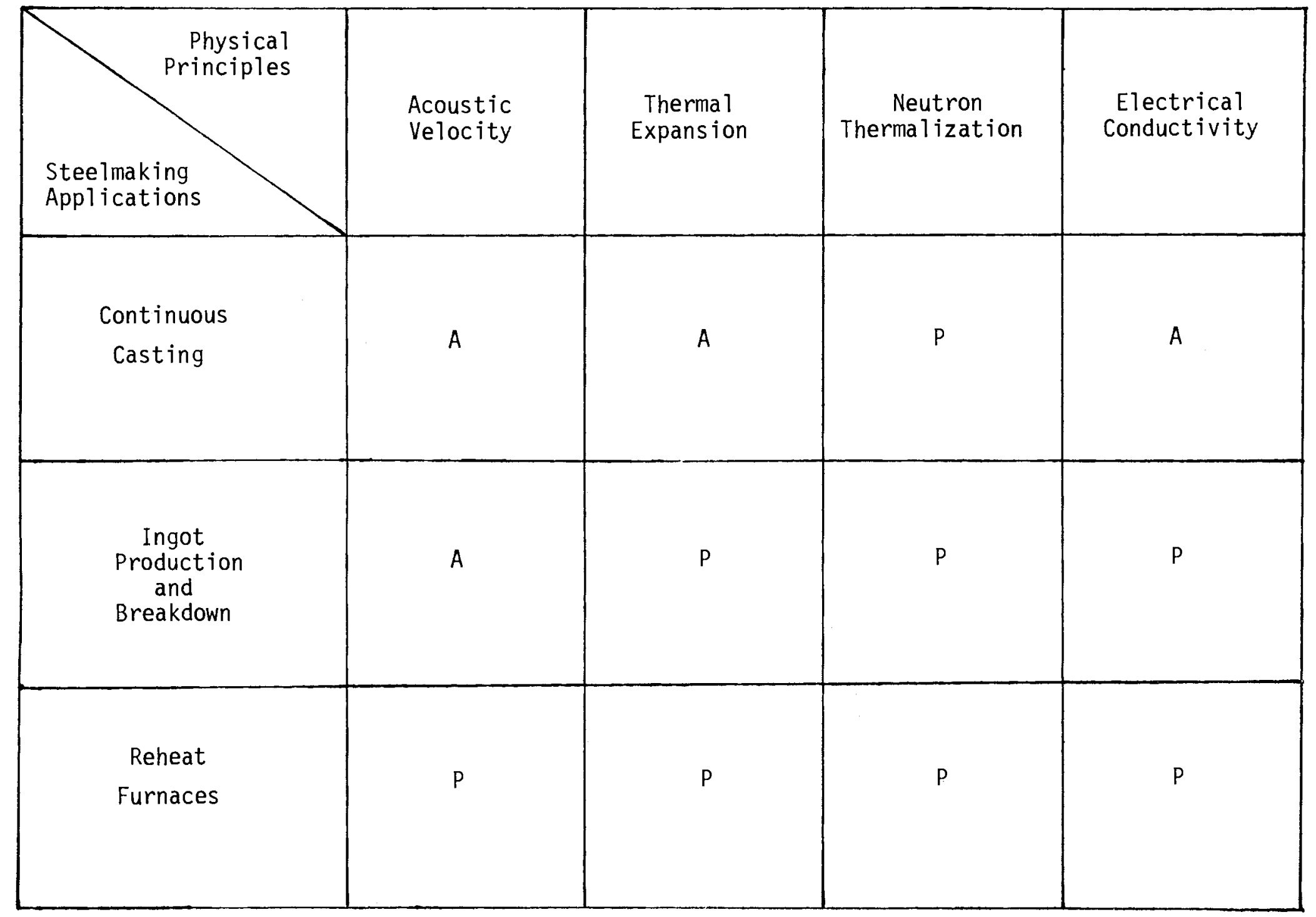

FIGURE. VIII-2. RESEARCH MATRIX COMBINING PHYSICAL PRINCIPLES WITH STEELMAKING APPLICATIONS 


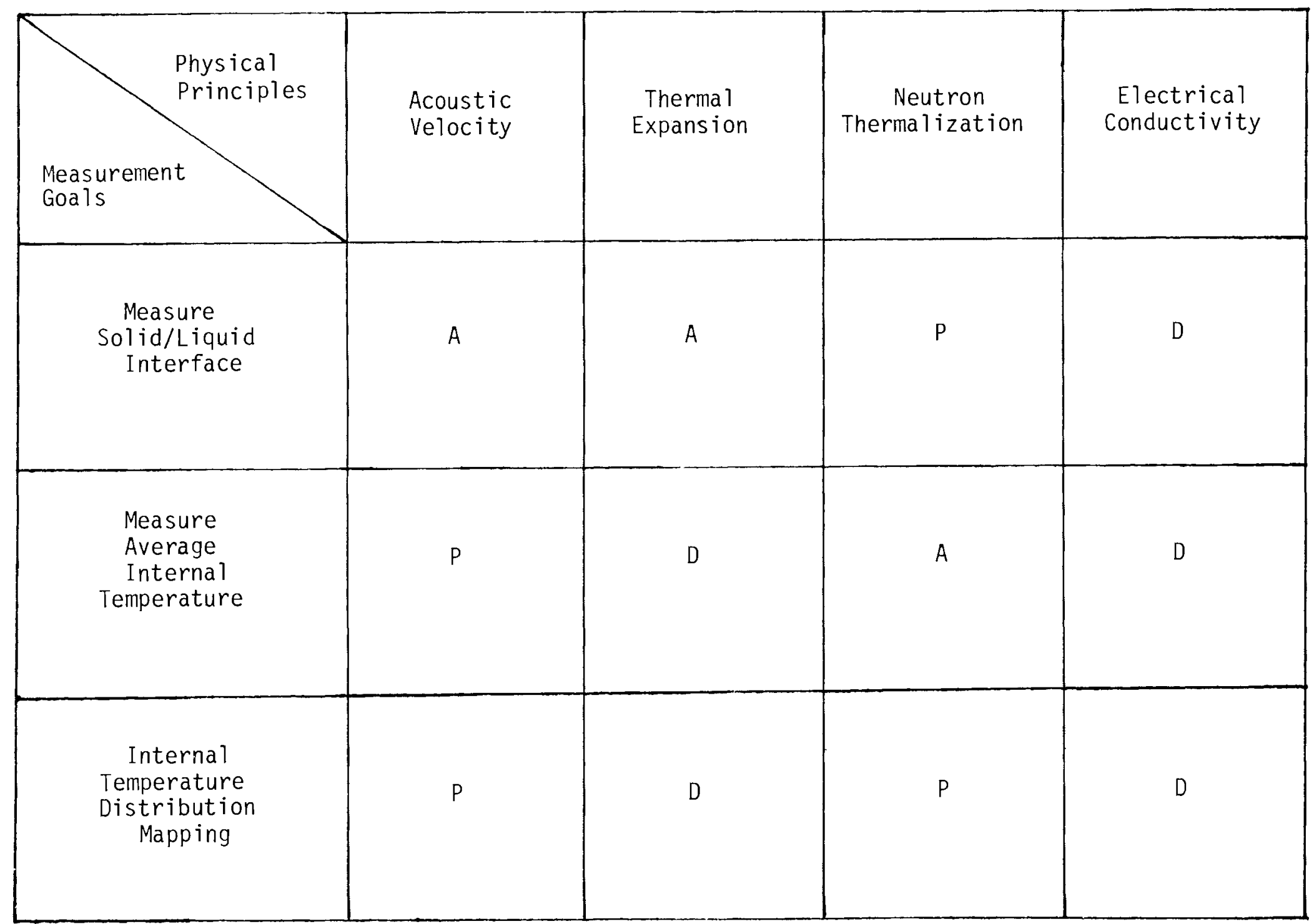

FIGURE VIII-3. RESEARCH MATRIX COMBINING PHYSICAL PRINCIPLES WITH MEASUREMENT GOALS 
Futhemore, it is helpful to identify several different research and development alternatives. These include:

- No further research

- Literature search

- Technical evaluation

- Laboratory research and development

- Field testing

- Use in production.

Armed with a set of matrices describing current activities, decision criteria, and an outline of possible research alternatives, it is possible to make specific research reommendations concerning each of the three different measurement goals.

\section{Real-Time Measurement of the Location} of the Solid/Liquid Interface

Most of the R\&D activity identified during this study involves measurement of the location of the solidification front during continuous casting. This observation indicates that prevention of breakouts and runouts is of primary concern to the steel industry. The tree diagram presented in Figure VIII-4 illustrates the different paths that have been tested. The dashed lines indicate that the techniques are thought to be under development, yet have not been reported in the scientific literature.

Clearly, the extent of research activity suggested by Figure VIII-4 indicates that almost any research undertaken by PNL might duplicate either current or past efforts to measure the solid/liquid interface. The risk involved in conducting research on such measurements is considered relatively low, because several of the systems are reported to have been successfully field tested. Finally, it is anticipated that commercial systems to detect the location of the solidification front may emerge in the near future. Based on these arguments, it is recommended that PNL not pursue research aimed at measuring the location of the solid/liquid interface. 


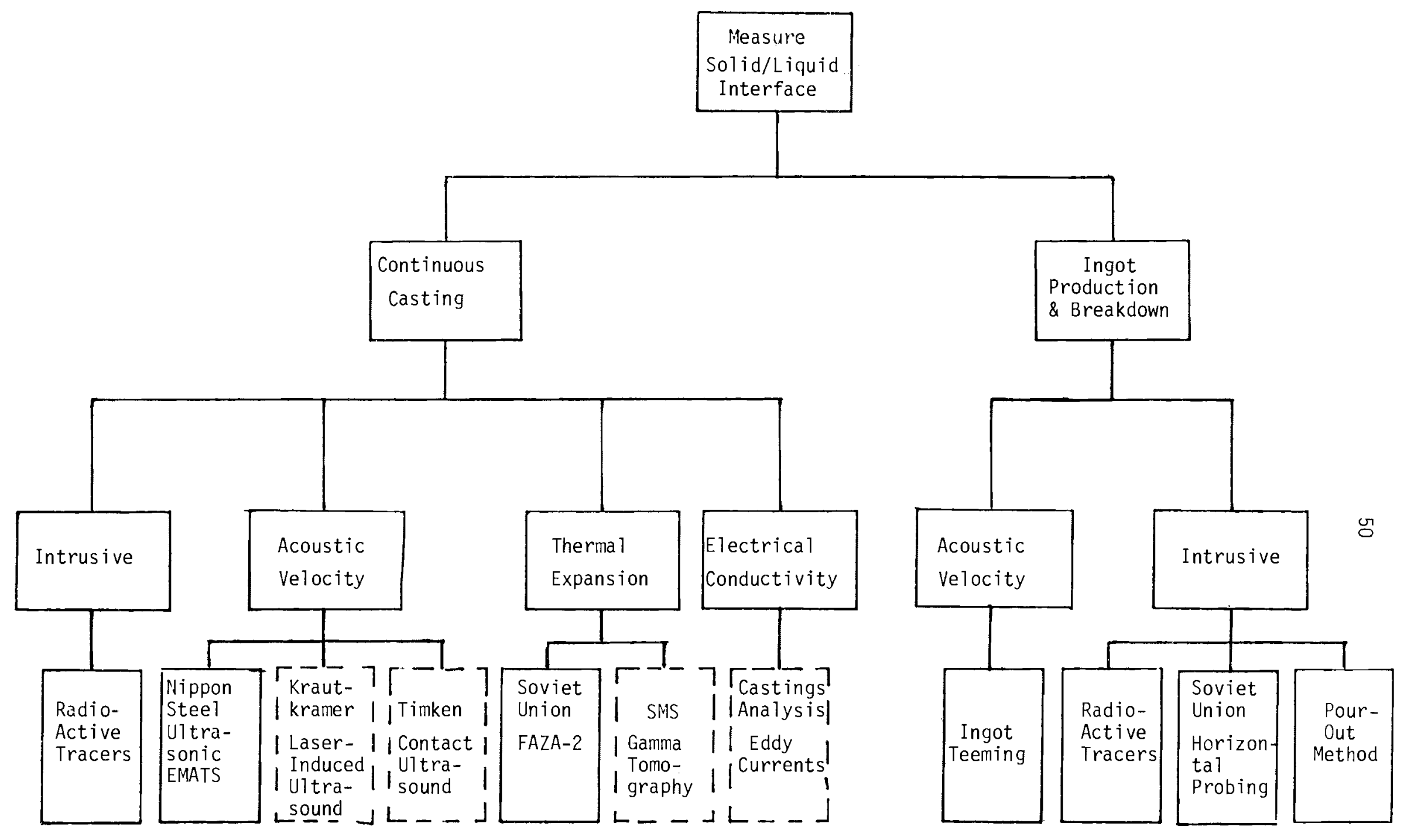

FIGURE VIII-4. TREE DIAGRAM OF EXISTING RESEARCH ALTERNATIVES TO MEASURE THE LOCATION OF THE SOLID/LIQUID INTERFACE OF STEEL DURING SOLIDIFICATION

Existing

-.--- Under Development 
Rea 1-Time Measurement of the Average Internal Temperature of Hot Steel Bodies

The tree diagram in Figure VIII-5 illustrates the research alternatives that have been suggested to measure the average internal temperature of hot steel bodies. Relatively little research activity was discovered concerning average internal temperature measurement. Therefore, duplication of research efforts is not considered likely.

There are two technologies that appear to be fairly well developed. The first is dilatometry, which the Soviets have been investigating in recent years. The Soviets reported successes on the laboratory scale in 1980. Whether the unit has been field tested or is in production is not known. Secondly, IRT Corporation has developed a prototype neutron thermalization sensor under DOE sponsorship. To our knowledge, however, extensive tests with steel have not been conducted.

Both the risk and the benefits associated with an average internal-temperature measurement appear moderate. One reason is that an average bulk-temperature measurement alone is not particularly useful in continuous casting where knowledge of the position of the solidification front is more important. This greatly diminishes the potential for widespread generic application. In furnaces, information about the magnitude of the temperature distribution may be of greater benefit than the average temperature. In short, measurement of the average internal temperature would be an improvement upon existing industrial temperature measurement, yet falls short of many process-control needs.

It is recommended that PNL not pursue average internal-temperature measurements as an overall objective, because the long-term benefits are considered too small to justify a major development program. 


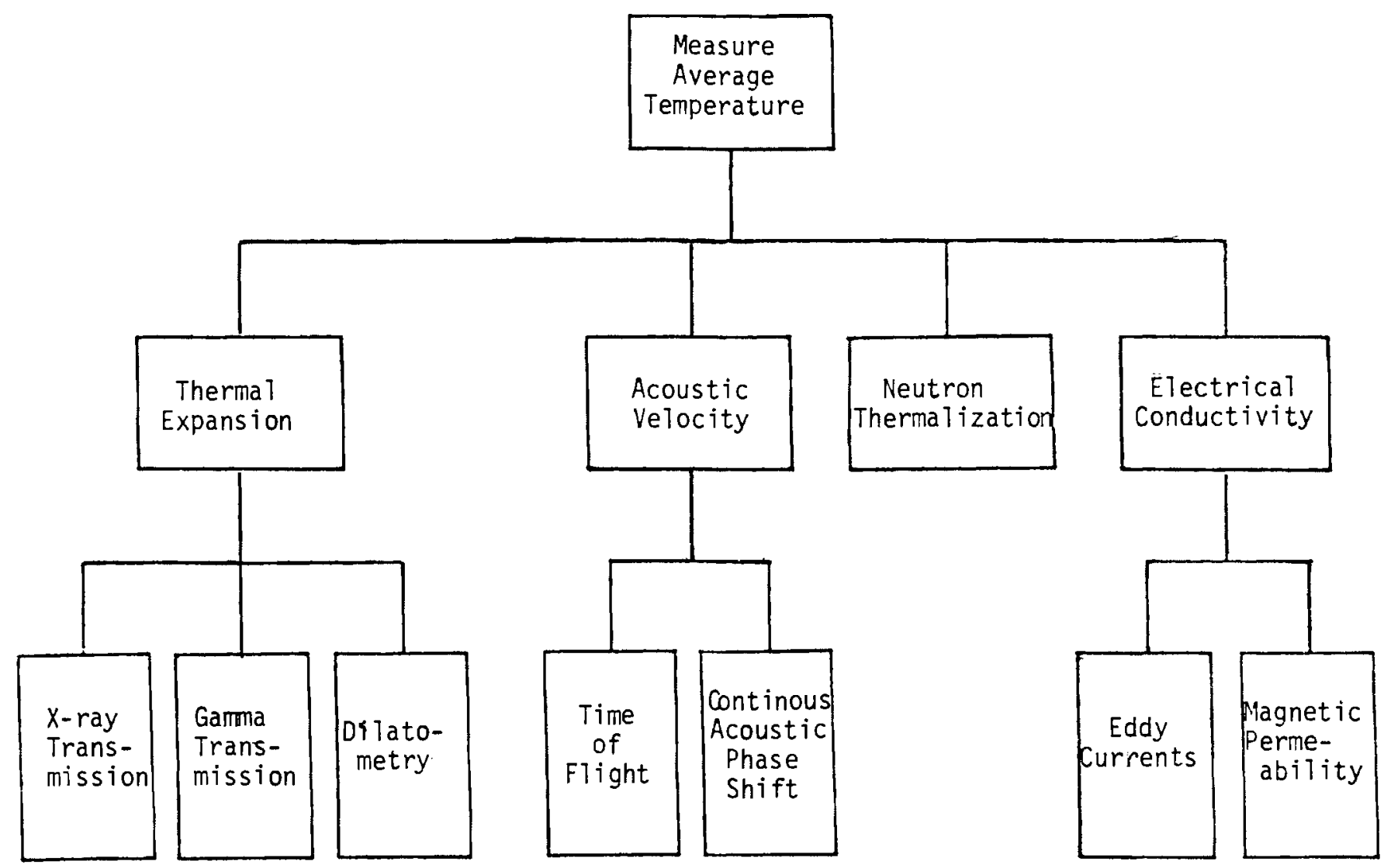

FIGURE VIII-5. TREE DIAGRAM OF RESEARCH ALTERNATIVES TO MEASURE AVERAGE INTERNAL TEMPERATURE OF HOT STEEL BODIES

- Possible techniques for measuring average internal temperature 
Rea7-Time Measurement of Internal-Temperature Distributions of Hot Steel Bodies

Measurement of internal temperature distributions has the widest generic application of the three proposed measurement goals. The location of the solid/liquid interface, the average internal temperature, and internal temperature gradients can each be derived from measurements of the internal temperature distribution. Therefore, internal temperature distribution mapping is at least as useful as the alternatives combined.

Although commercial systems for measuring internal temperature distributions in steel are being developed for specific applications, no generic device is currently available nor known to be under development. It is possible that a single generic solution does not exist. On the other hand, if a generic device were developed, its use in the steel industry represents a potential energy savings estimated at 0.8 quad per year.

It is recommended that PNL pursue measurement of internal temperature distributions in hot steel bodies as its principal research objective.

The tree diagram in Figure VIII-6 shows the research alternatives for measuring internal temperature distributions in hot steel. The solid ines represent systems in current use. The dashed lines represent systems thought to be in development. The alternating dash-dot lines represent untested aiternatives.

The most readily available commercial system is Fedesco's STOR thermocouple system for monitoring the internal temperature distribution of slabs in reheating furnaces. However, embedded thermocouples are intrusive and therefore do not satisfy the requirements for a continuous real-time nondestructive measurement.

Electrical conductivity and magnetic permeability might be used to determine internal temperature distributions in steel. Castings Analys is is exploring these techniques in attempting to develop systems for monitoring internal temperature distributions and solidification for the aluminum and steel industries. No commercial systems yet exist.

Castings Anatysis uses eddy current measurements and mathematical conversion techniques pioneered by geophysicists to construct a model of the electrical conductivity profile of the spectrum. The inversion techniques may yield more than one solution, requiring additional data interpretation. 


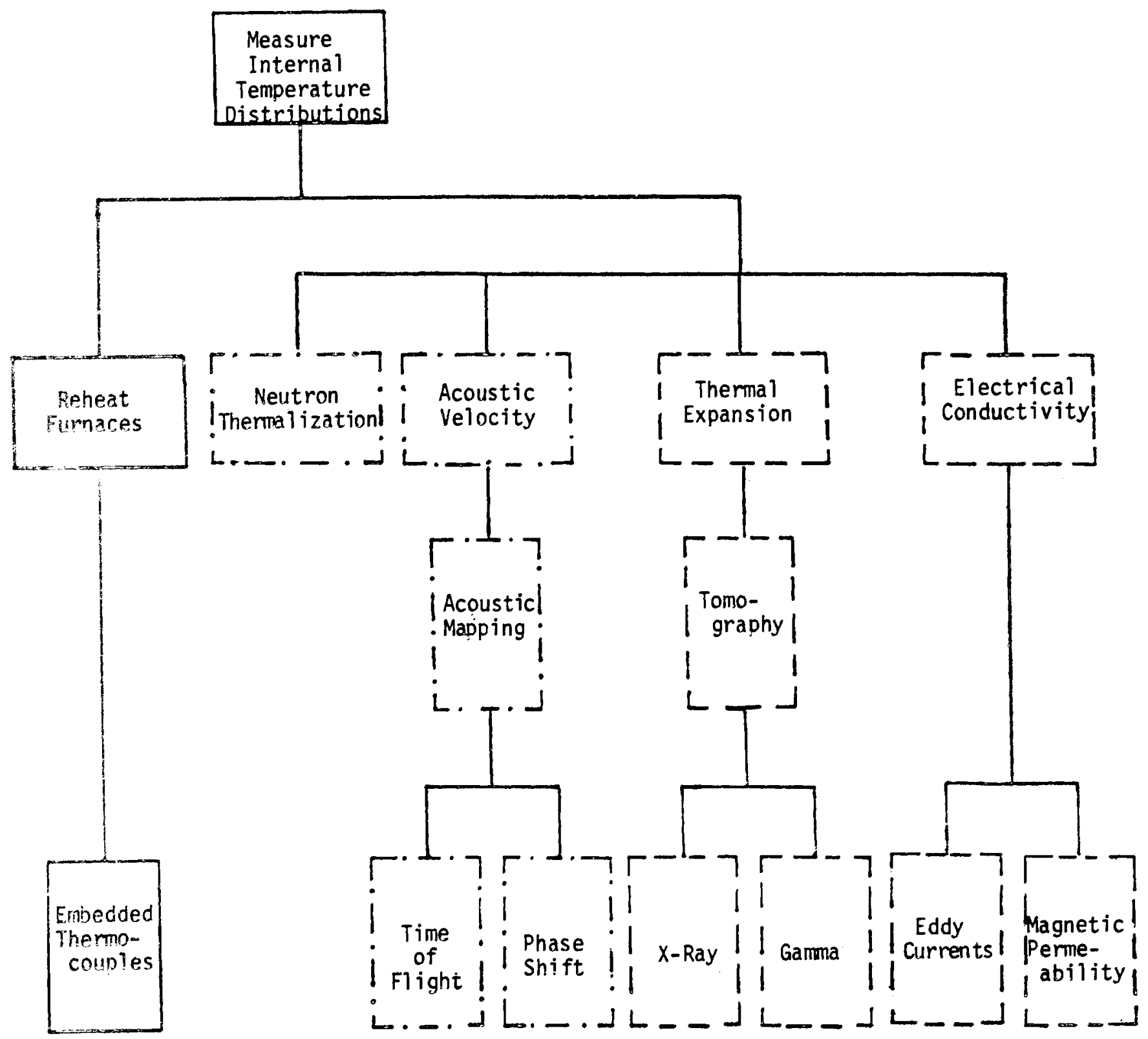

FIGURE VIII-6. TREE DIAGRAM OF RESEARCH ALTERNATIVES TO MEASURE INTERNAL TEMPERATURE DISTRIBUTIONS OF HOT STEEL BODIES

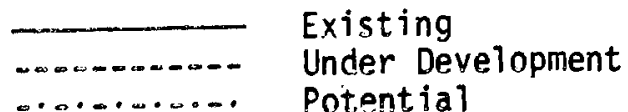


Below the magnetic Curie point, the mathematical analysis becomes more difficult and requires measurement of permeability variations in addition to conductivity.

Tomographic systems using gamma attenuation measurements are being developed by the SMS Corporation for industrial applications in the steel industry. Their systems are capable of reconstructing internal temperature distributions in tubular products and billets. The sensitivity of $x$-rays and gamma to density changes is expected to require increasingly higher flux densities to obtain the desired degree of resolution, especially for large specimens.

Neutron thermalization techniques might be used to measure internal temperature distributions in steel. A single neutron transmission measurement yields an integrated average temperature weighted more heavily toward the surface. A series of neutron transmission measurements might be used to reconstruct internal temperature distributions. During this survey, we did not encounter any suggestions that neutron thermalization techniques be applied to perform temperature distribution mapping.

Similarly, it has been suggested that a series of acoustic velocity measurements be used to reconstruct the internal temperature distributions. The temperature dependence of acoustic velocity, as shown in Figures $V-2$ to $V-4$, can be determined experimentally with small samples of uniform temperature. Real-time measurement during steel production involves large volumes of steel, with the temperature nonuniformly distributed throughout the volume. A complex series of acoustic velocity measurements would be required to reconstruct the internal temperature distributions.

Acoustic velocity measurements are currently being developed for determining the location of the solid/liquid interface during steel solidification. No one was found to be pursuing average (integrated) temperature measurement or temperature distribution mapping using acoustic velocity techniques. However, the experience and hardware under development for measuring the location of the solidification front in steel provides a good starting point for attempting temperature-distribution mapping. Advances in the development of electromagnetic acoustic transducers (EMATS) and laser-induced ultrasound exhibit a strong potential for remote sensing. Remote sensing may be necessary for widespread generic application of the technology. 
Acoustic velocity is not dependent solely upon temperature. Other factors, including chemical composition, microstructure, internal stresses, and variation of modulus can affect the velocity. The extent to which these physical characteristics of the steel affect acoustic velocity is not known at this time. If these interdependencies were sorted out, it may be possible to simultaneously ineasure variations in modulus, internal stresses, and internal temperature distributions. A substantial research and development effort would be needed to arrive at such a system.

A combination of physical principals may be required to measure the internal temperature distribution. However, limited resources are available. If only one technology is to be selected to initiate a sensor development program, it is recomended that research be focused on acoustic mapping techniques, which appear to represent the most generic solution to measurement of internal temperature distribution for all of the steel applications considered. The alternatives, ranked in order of decreasing preferences, are perceived to be: electrical conductivity; gamma tomography and neutron thermalization.

The real-time measurement of internal temperature distributions in bodies of hot steel is a difficult assignment. Step-by-step evolutionary research can be expected to be time-consuming and expensive. There is a substantial risk that even a large investment in research and development might not yield a practical solution within a reasonable period of time. What is really needed is innovation and a flash of genius. These resist scheduling and programming. However, a program of evolutionary research can establish conditions that encourage innovation.

The level of activity required in the next phase of a sensor development program probably combines focused technical analys is with preliminary laboratory investigations. Several basic questions need to be addressed. Among these are:

- Would systems combining measurements based on different physical principals be more effective than systems relying on a single temperature-dependent physical phenomenom?

- Can the temperature dependence of the acoustic velocity be isolated from non-temperature-related phenomena that also effect acoustic velocity?

- What type of acoustic measurement, whether it be phase shift, time of flight, or some other, would be adequately sensitive to temperature? 
- Does the hardware exist for transmitting and receiving acoustic waves in hot steel bodies?

What further developments are necessary? 
REFERENCES 
1. Mairy, B., Ramelot D., Ironmaking and Steelmaking, No. 2, 91, 1981.

2. Roney, J. E., "Steel Surface Temperature Measurement in Industrial Furnaces by Compensation for Reflected Radiation Errors". Presented at the Sixth Temperature Symposium and Exhibit, Washington, D.C., March 15-18, 1982 .

3. Owen, E. J., "Thermographic Techniques as Applied in the Australian Steel Industry". Ninth World Conference on Non-Destructive Testing, Melbourne, Australia, 18-23 November 1979.

4. Hashio, M., Kimura, T., Kato, H., Watanabe, T., "Control of Slab Surface Temperature in Continuous Casting," 97th ISIJ Meeting, Lecture No. 5.120; Apri1 1979.

5. Carbinagno, G. M., Berardi, P. G., "Unsteady Thermotopography in Non-Destructive Testing, " Proceedings of the Bienn Infrared Inf., Exch., 3rd. St. Louis, Missouri, August 24-26, 1976, published by AGA Corp Secaucus, New Jersey, pp 33-40, 1977.

6. Houseman, D. H., "Radioisotope Studies of Steel Ingot Solidification," Steel Times V/92, No. 5106, p 689-695, May 27, 1966.

7. Zeder, H., Hedstrom, J., "Determination of the Solidification Front in Continuously Cast Billets, Using Radioactive Isotopes, "Radex Rundsch N 2, p 407-418, Apri1 71.

8. Kazachkov, E. A., Revto, N. I., Fedorov, V. A., "Kinetics of Crystallization of Large Killed and Semi-Killed Steel Ingots," Steel USSR, V.3, n.9, p 734-735, Sept. 1973.

9. Federal Equipment and Supply Company, Thermophil Datasheet 4466/67.

10. Patrick Slepekis, Fedesco, Private Communication, 22 April 1982.

11. Krivosheav, E. E., Belai, G. E., Ivanushkin, E.S., Starkov, K. A., "Ultrasonic Methods for Monitoring the Solidification of Cast Iron in Mould," Izv. VUZ Chernaya Meta11, (6), pp 123-127, 1975.

12. Kurz, W., Lux, B., "Location of the Solidification Front in Continuous Casting of Stee1," Berghutten mann Monatsh, 114 (5), pp 123-130, May 1969.

13. Kurz, W., Luz, B., "Localization of the Solid Liquid Interface in Metals hy UTtrasonic Methods," Z. Metallkunde, 57 (1), pp 70-73, ?aridary 7966.

14. Lavender, J. D., "Transmission of U1trasonic in Liquid Steel and Measurement of U1trasonic Attenuation During Cooling", Non-Destructive Testing, 5 (2), pp 107-109, April 1972. 
15. Battelle Pacific Northwest Laboratories, "Development of Ultrasonic Tomography for Residual Stress Mapping," EPRI Np-1407, May 1980.

16. Kawashima, K., Nakamori, Y., Murota, S., Soga, H., "In-Line Nondestructive Measurement of Solidification Shell Thickness of C.C. Slabs," 98th ISIJ Meeting, No. S712, October 1979.

17. Kawashima, K., Murota, S., Nakamori, Y., Soga, H., Suzuki, H., "Electromagnetic Generation of Ultrasonic Waves in Absence of External Magnetic Field and Its Application to Steel Production Lines, "Ninth. World Conference on Non-Destructive Testing. Melbourne, Australia, 15-23 November 1979.

18. Masao Takeda, Nippon Steel, private communication, 22 February 1982.

19. Jeskey, G. V., Lynnworth, L. C., Fowler, K. A., "Ultrasonic Transmission Technique for Real Time Monitoring of Steel Solidification," AFS Int. Cast Met J., 2 (4), pp 26-30, December 1977.

20. Papadakis, E. P., Lynnworth, L. C., Fowler, K. A., Carnevale, E. H., "Ultrasonic Attentuation and Velocity in Hot Specimens by the Momentary Contact Method with Pressure Coupling and Some Results on Steel to 1200C," Jnl Acoustic Soc. of Am., b2 (3), pp 850-857, 1972.

21. Destate, J. C., Joannes, R., Pesch, R., Pirlet, R., "Acoustic Measurement of Rimming in Steels," Metall Rep. CRM, n41, pp 19-28, December 1974.

22. Meshcheryaka, A. S., Blinov, 0. M., "The Thermodilatometric Method for Monitoring Metal Temperature in Furnaces," Izv. VUZ Chernaya Metal1., (5), pp 140-143, 1980.

23. Deryabina, G. N., Ripp, A. G., "Measuring the Ratio of Liquid Phase to Solid Phase in a Continuous Ingot," Defektoskopiyu 10, pp 20-28, October 1980.

24. Deryabina, G. N., "Monitoring the Thickness in a Continuously Cast Strand," STAL, (5), p 375, May 1980.

25. Deryabina, G. N., "Controlling Thickness of Skin of Continuously Cast Billet," Steel USSR, 10 (5), p 249, May 1980.

26. Vagelatos, N., Steinman, D. K., John J., "True Formation Temperature Sonde (TFTS)," SPWLA Twentieth Annual Logging Symposium, June 3-6, 1979.

27. Vagelatos, N., Steinman, D. K., John, J., Young, J. C., "Method and Apparatus for Determination of Temperature Neutron Absorption Cross Section and Neutron Moderating Power," U.S. Patent 4,251,724, February 17, 1981.

28. Schwerer, F. C. and Cuddy, L, J., "Spin-Disorder Scattering in Iron and Nickel-Base Alloys," Phys Rev. B 2 (6), pp 1575-1586, September 1970. 
29. Wallace, J. P. and Kunerth, D. C., "Eddy Current Response to Metallic Solidification in One Dimension, "Met. Trans B., 11B (2), pp 267-271, 1980 .

30. Kunerth, D. C. and Wallace, J. P., "Eddy Current Study of Solidification of Lead and Lead 20 Percent Tin," Met Trans 11B (2), pp 273-283, 1980.

31. Findlay, R. D., "Field Distributions in an Inductively Heated Non-Magnetic Billet of Finite Length," IEEE Trans Ind. Gen. AppI., IGA-6 (5), pp 497-502, September-October 1970.

32. Wallace, J. P., Kunerth, D. C., Siegfried, R. M., "An Eddy-Current Study of Casting," ASTM STP, 722, pp 173-136, 1981.

33. Wallace, J. P., Kunerth, D. C., Siegfried, R. M., "Eddy Current Measurements in Steel Processing," to be published in Physics in Steelmaking, AIP-AISI 1982.

34. Institute for Iron and Steel Studies, "Input-Output III. Continuous Casting - Indispensable Technology," IISS Commentary, X-5, IISS, Green Brock, New Jersey, May 1981.

35. Battelle Columbus Laboratories, "Final Report on Potential for Energy Conservation in the Steel Industry, Federal Energy Administration, NTIS, PB 244097/AS, May 30, 1975.

36. Lownie, H. W., McLeer, T. J., Swager, W. L., Varga, J., Kura, J. G., Hazard, H. R., Pierson, W. R., Demetrops, J. P., "Final Report on Implementation of Energy Conservation Technology in the Stee 1 Industry," Vo 1. 1, p 5-11, U. S. Dept of Energy, Office of Industrial Programs, Washington, D. C., August 1980.

37. Arthur D. Little, Inc. "Research, Development and Demonstration for Energy Conservation: Preliminary Identification of Opportunities in Iron and Steelmaking," U. S. Dept of Energy, Division of Industrial Energy Conservation, Washington, D. C., January 1978.

38. 33 Metal Producing editorial staff, "World Steel Industry Data Handbook, Vol. 1, The United States," McGraw Hi11, New York, New York, 1978.

39. Ishihara, S., "Latest Advances in Bulk Steelmaking Technology, "presented at 15th Annual Meeting of the International Iron and Steel Institute, Toronto, Canada, October 11-14, 1981; Nippon Steel News, January 1982.

40. Cook, J. R., Nenni, J. T., and Dishun, T. R., "Minimization of Fuel Consumption in Soaking Pits Using a Cylindrical Equivalent Model for On-Line Estimation of Ingot Thermal Profiles", Paper presented at 65th Steelmaking Conference of the AIME, Pittsburgh, March 28-31, 1982. 
. 
APPENDIX A

Survey Guide and Flowchart 
1. Current practices

(a) Where do you measure and control temperatures? (stripping yard, soaking pits, blooming/slabbing mill, bar mills. strip mill, concast machine)

(b) What instruments are now used?

(Optical pyrometer, radiation pyrometer, etc.)

(c) Continuous observation, intermittent, etc.

(d) Manual, automated, or computer control?

2. What are the problems or deficiencies with current practices?

3. How could improvements conserve energy?

4. What developments, if any, are in progress to overcome current problems or deficiencies?

5. What would you recommend for R\&D to improve present situation?

6. In what other areas are improved sensors needed?

7. What, if any, R\&D is in progress to develop them?

8. Who do you suggest we contact for information on other areas? 


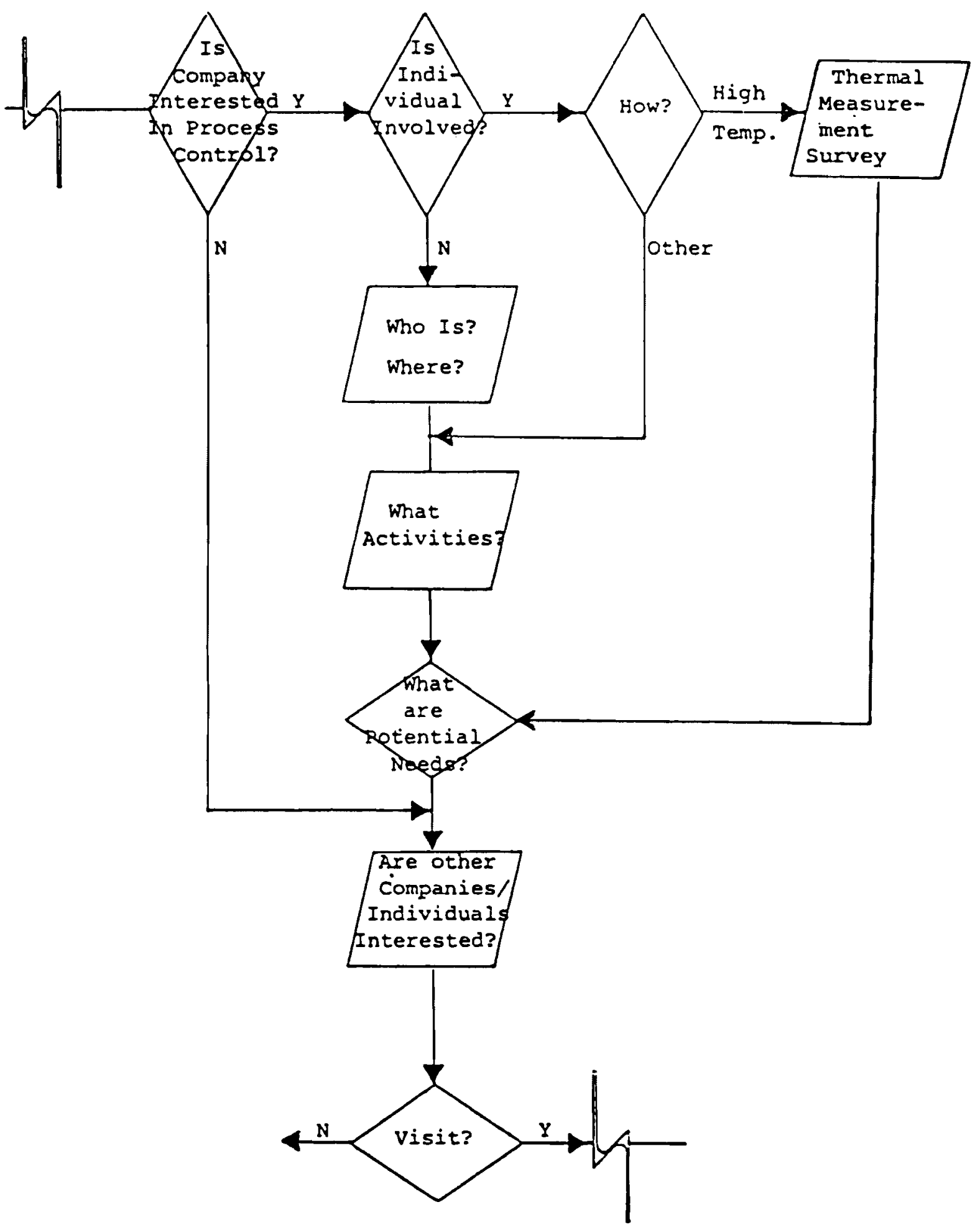


APPENDIX B

List of

Individuals Contacted

During the Study 

American Iron and Steel Institute

Dr. William E. Dennis

Mr. Robert D. Jeffress

Armco Incorporated

Or. James R. Cook

$\mathrm{Mr}$. Thomas R. Dishun

Bethlehem Steel Corporation

Dr. Vincent $V$. Horvath

Canadian Iron and Steel Research Association

Mr. Eric W. Leaver

Hoogovens Imjuiden, B. U.

Mr. F. Hollander

Inland Steel Company

Dr. Howard Pielet

Jones and Laughl in Steel Corp.

Mr. J. E. Roney

National Steel Corporation

Mr. Robert S. Miltenberger

Mr. Richard Morgan

Dr. Walter A. Wilson

Mr. Joseph Rzlpka

Dr. Reginald Dietz

Mr. William D. Rahr

Mr. John Hellander

Mr. Richard Sikola

Nippon Steel Corporation

Mr. Masao Takeda 
Republic Steel Corporation

Dr. Leonard R. Stone

$\mathrm{Mr}$. Robert J. Watson

$\mathrm{Mr}$. Wallace B. McLearnon

$\mathrm{Mr}$. A. I. Koler

Mr. David McLaughlin

Mr. Glenn C. Bradler

$\mathrm{Mr}$. R. H. Wallace

Timken Co.

Mr. Gerald Jeske

United States Steel Corp.

Mr. Ralph G. Rudolph

$\mathrm{Mr}$. Blair Henry

$\mathrm{Mr}$. Frederick C. Schwerer

$\mathrm{Mr}$. Arnold Rohr

AccuRay

Dr. William Adams

Battelle Pacific Northwest Laboratories

Dr. Gerald J. Posakony

Beckman Instruments

Mr. Lloyd Bostwick

$\mathrm{Mr}$. James Floeck

Bell Laboratories

Mr. Richard Klinman

Exxon Engineering Technology

Dr. Alex Stein

Ford Motor Company

Dr. Emmanuel Pappadakis

Foxboro

Mr. Jack Martin

Mr. Greig Shinsky

Mr. John Chang 
Honeywe 11

Mr. Richard Daubens

$M r$. Edward Pisarez

Mr. James Brosvic

Krautkramer

Mr. Charles Vassallo

IBM Corp.

Dr. Robert Melcher

IRT Corp.

Dr. Nicholas Vagelatos

Panametrics

Mr. Lawrence C. Lynnworth

$\mathrm{Mr}$. Kenneth A. Fowler

Scientific Measurement Systems, Inc.

Dr. I. L. Morgan

Schlumberger

Dr. James Hall

Southwest Research Institute

Dr. Cecil Teller

Spectron Development Laboratory

Dr. B. Percy Hildebrand

$\mathrm{Mr}$. Thomas Davis

Westinghouse

Mr. Edward Friedman

Ames Research Laboratory

Dr. D. 0. Thompson 
Jet Propulsion Laboratory

Dr. J. Pierce

Dr. Nakamura

Lawrence Livermore National Laboratory

Mr. Henry Freynick

$\mathrm{Mr}$. J. J. Ronchetto

NASA Regional Technical Information Centre

$\mathrm{Mr}$. Robert Kenney

Nationa 1 Bureau of Standards

Dr. Robert Parker

Dr. James Schooley

Mr. Harold Berger

Or. Christopher Fortunko

Oak Ridge National Laboratory

Mr. Anthony Schaffhauser

Mr. McClung

Sandia National Laboratory

Dr. Raymond Reed

Dr. William Drotning

Dr. G. A. Carlson

U. S. Geological Survey

Mr. William C. Cannon

Mr. Philip Bethke

Mr. Gary 0lhoeft

Wright Aeronautical Laboratories

Dr. Norman Tallan

Mr. Attwell Adair 
B-5

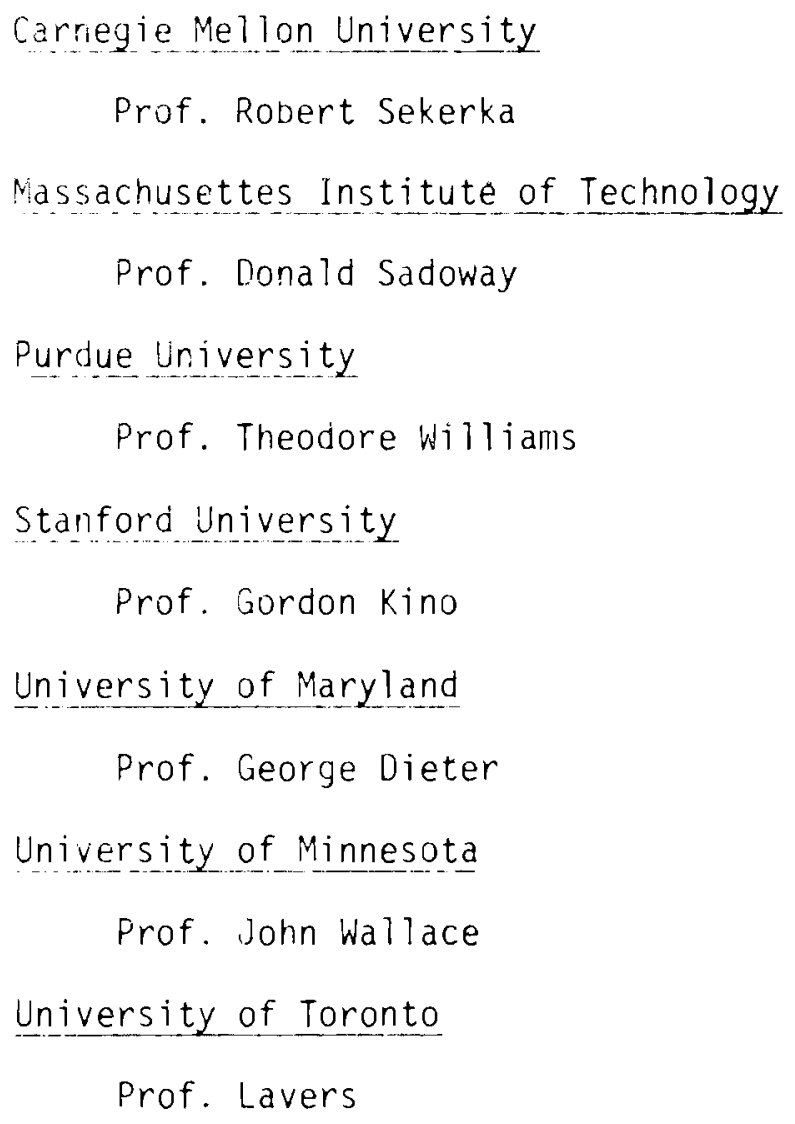




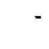

. 
No. of

Copies

\section{OFFSITE}

A. A. Churm

DOE Patent Office

9800 S. Cass Avenue

Argonne, IL 60439

Alan Streb

Department of Energy

Office of Industrial

Programs

Forrestal Building

Washington, D.C. 20585

Tom Gross

Department of Energy

0 ffice of Industrial

Programs

Forrestal Building

Washington, D.C. 20585

Ernest Loeb

Department of Energy

office of Industrial

Programs

Washington, D.C. 20585

John Rossmeissl

Department of Energy

Office of Industrial

Programs

Forrestal Building

Washington, D.C. 20585

John Eust is

Department of Energy

Office of Industrial

Programs

Forrestal Buildings

Washington, D.C. 20585

Ralph Sheneman

Department of Energy

office of Industrial

Programs

Forrestal Buildings

Washington, D.C. 20585

No. of

Copies

\section{OFFSI TE}

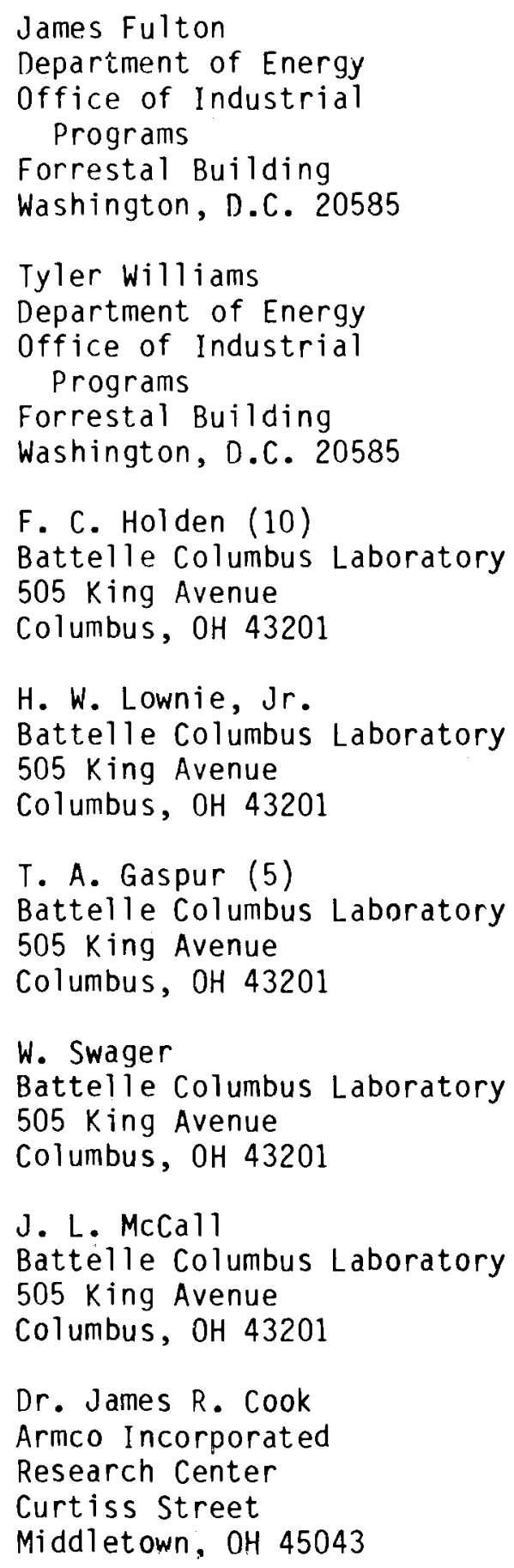




\section{DISTRIBUTION}

No. of

Copies

OFFSITE

Dr. Vincent V. Horvath Homer Research Laboratories Bethlehem Steel Corporation Bethlehem, PA 18016

Dr. Howard Pielet

Inl and Steel Research Laboratories Inland Steel Company

3001 East Columbus Drive

East Chicago, IN 46312

Mr. Ralph G. Rudolph

United States Steel Corporation

Research Laboratory - MS \#67

125 Jamison Lane

Monroeville, PA 15146

Dr. William E. Dennis

Vice President - Manufacturing and Research

American Iron and Steel Institute 1000 16th Street, N.W.

Washington, D.C. 20036

Paul Frost

Battelle Columbus Laboratory

$505 \mathrm{King}$ Avenue

Columbus, $\mathrm{OH} 43201$
No. of

Copies

OFFSITE

Mr. Robert D. Jeffress

Staff Representative

American Iron and Steel Institute 1000 16th Street, N.W.

Washington, D.C. 20036

Mr. R. L. Whiteley

Bethlehem Steel Corporation

Homer Research Laboratories

Bethlehem, PA 18016

246 DOE Technical Information Center

DOE Richland Operations office

H. E. Ransom

28 Pacific Northwest Laboratory

C. H. Bloomster

M. Clement (10)

N. L. Moore

J. W. Reis

R. W. Vallario

L. D. Williams

T. A. Williams

Publishing Coordinator (2)

Technical Information (5)

Energy Systems Library (5) 
